\title{
Development of a High-Resolution Multiscale Modeling and Prediction System for Bay of Bengal, Part I: Climatology-Based Simulations
}

\author{
Arun Chakraborty ${ }^{*}$, Avijit Gangopadhyay ${ }^{1,2,3}$ \\ ${ }^{1}$ Centre for Oceans, Rivers, Atmosphere and Land Sciences (CORAL), Indian Institute of Technology Kharagpur, \\ Kharagpur, India \\ ${ }^{2}$ School of Earth, Ocean and Climate Sciences, Indian Institute of Technology Bhubaneswar, Bhubaneswar, \\ India \\ ${ }^{3}$ School for Marine Science and Technology, University of Massachusetts Dartmouth, USA \\ Email: *arunc@coral.iitkgp.ernet.in, agangopadhya@umassd.edu
}

Received 2 December 2015; accepted 26 January 2016; published 29 January 2016

Copyright $@ 2016$ by authors and Scientific Research Publishing Inc.

This work is licensed under the Creative Commons Attribution International License (CC BY).

http://creativecommons.org/licenses/by/4.0/

(c) (i) Open Access

\begin{abstract}
A high-resolution $(10 \mathrm{~km} \times 10 \mathrm{~km})$ multiscale ocean modeling system was developed for shortterm (1 - 2 weeks) ocean state hindcasting/forecasting in the Bay of Bengal (BOB) region. This paper is Part I of a two-part series of studies. The Regional Ocean Modeling System (ROMS) was implemented and initialized with Levitus $1 / 4^{\circ}$ climatological fields for short-term forecasting. The results from these climatology-based model simulations for three representative months (February, June and October) in three different seasons (winter, summer and autumn) are discussed herein. This high-resolution model implementation simulates most of the observed dominant circulation features. The multiscale features during February include an anticyclonic basin-scale gyre with a strong western boundary current (WBC) in the western basin, the formation of several shallow mesoscale eddies in the head of the Bay and a cyclonic sub-basin-scale Myanmar Gyre in the northeast. During June, no well-defined boundary current is simulated along the Indian coast; instead, alternating cyclonic and anticyclonic eddies appear along the east coast with cross-basin eastward flow to support a deep cyclonic Andaman Gyre. In October, a basin-scale cyclonic gyre with a continuous well-defined East India Coastal Current (EICC), weak inflow from the Malacca Strait to the Andaman Sea and advection of BOB water into the Arabian Sea via the Palk Strait are simulated well by the model. A number of mesoscale eddies appear on the eastern half of the basin during October. Physical pattern of simulated eddies and transports across selected sections are validated against available drifter climatology, ARGO data and previous observations. Application
\end{abstract}

"Corresponding author.

How to cite this paper: Chakraborty, A. and Gangopadhyay, A. (2016) Development of a High-Resolution Multiscale Modeling and Prediction System for Bay of Bengal, Part I: Climatology-Based Simulations. Open Journal of Marine Science, 6, 145-176. http://dx.doi.org/10.4236/ojms.2016.61013 
of this system to synoptic short-term predictions for October 2008 will be presented in Part II.

\author{
Keywords
}

Simulation, Bay of Bengal, WBC, EICC

\title{
1. Introduction
}

The importance of predicting the state of the ocean (currents, temperature, salinity and sea level) in real time has long been recognized. Recently, the Integrated Ocean Observing System (IOOS,

http://oceanservice.noaa.gov/facts/ioos.html), Global Ocean Observing System (GOOS, http://www.ioc-goos.org) and GOOS in the Indian Ocean (IOGOOS, http://www.incois.gov.in/portal/iogoos/home.jsp) have given impetus to different countries to focus on regional ocean prediction research. The GOOS program is a permanent system for observation, modeling and analysis of ocean variables to support operational ocean services for the globe. The goal of IOGOOS is to promote activities for the development of operational oceanography in the Indian Ocean region [1]. Based on this motivation, a real-time ocean hindcast/forecast system is being developed for the Bay of Bengal (BOB) region, which is a tropical ocean basin with three sides bounded by land and an open southern boundary (Figure 1(a)).

Typically, there are two ways to set up the initialization field for an ocean prediction modeling system. In one method, the model is first spun up to equilibrium with climatological water-mass fields forced with atmospheric fields over a period of time (typically 3 - 10 years) [2]. Available data are then assimilated with realistic (and real-time) atmospheric model forecast fields in the prognostic mode. Various assimilation schemes such as nudging [3] [4], Objective Interpolation (OI) [5], 3DVAR [6] [7] and 4DVAR [8] [9] are employed to maximize data utilization and minimize model-data differences at the observation locations. Examples of such prediction systems are the Global Ocean Data Assimilation Experiment (GODAE, http://www.godae.org), Hybrid Coordinate Ocean Model (HYCOM, http://www.hycom.org), Navy Coastal Ocean Model (NCOM, http://www7320.nrlssc.navy.mil/global_ncom), UK Met Office (http://www.metoffice.gov.uk) model, and the models run by the Bureau of Meteorology, Australia (http://www.bom.gov.au). In the second method, the initialization field is obtained by a careful reconstruction of the three-dimensional ocean with prevalent mesoscale and submesoscale features embedded in an appropriate climatology [10]-[12]. Typical data assimilation and forcing are applied during the forecast period.

The first method works well when there are adequate observations available in space and time and when these observations sample the dominant variability of the system. The second method works well when prior knowledge of the regional synoptic variability has been captured well by regional feature models that are first validated and then employed for initialization. The former method is applicable to targeted sampling of a particular phenomenon, while the latter depends on the persistence and robustness of the dominant circulation features. Both of these methods require climatological fields as background, and it is the fidelity of the climatology that determines the robustness of the prediction system.

The circulation system in the Bay of Bengal consists of a complex interplay of seasonally robust fronts/currents with transient eddies superimposed on a background of seasonally changing large-scale gyres. The scarcity of data (both historical and in real time) makes developing a real-time prediction system a challenging task. Our approach was to develop such a system in two phases. First, as described herein, we implemented a high-resolution regional modeling system initialized with the available high-resolution climatological data to help us understand the fidelity of the climatological fields in developing robust, large-scale currents/fronts and gyres and probably a number of mesoscale features. This step was carried out individually for three particular months that represent the three seasonal variation phases of the Bay's monsoon-dominated circulation pattern: the pre-monsoon (February), monsoon (June) and post-monsoon (October) periods. In the second phase, we investigate the impact of introducing SST and ARGO data into the climatological background for October 2008. Together, these two studies establish a modeling framework for developing a fully operational forecast system following either (or both) of the two well-known approaches discussed above.

Several modeling [13]-[18], observational [19]-[26] and ship-drift [27] studies have shown a distinct seasonal cycle of surface circulation, with seasonally reversing coastal currents along the eastern coast of India in the Bay of Bengal. During the month of February, the prominent surface circulation feature in the Bay is a basin-scale 


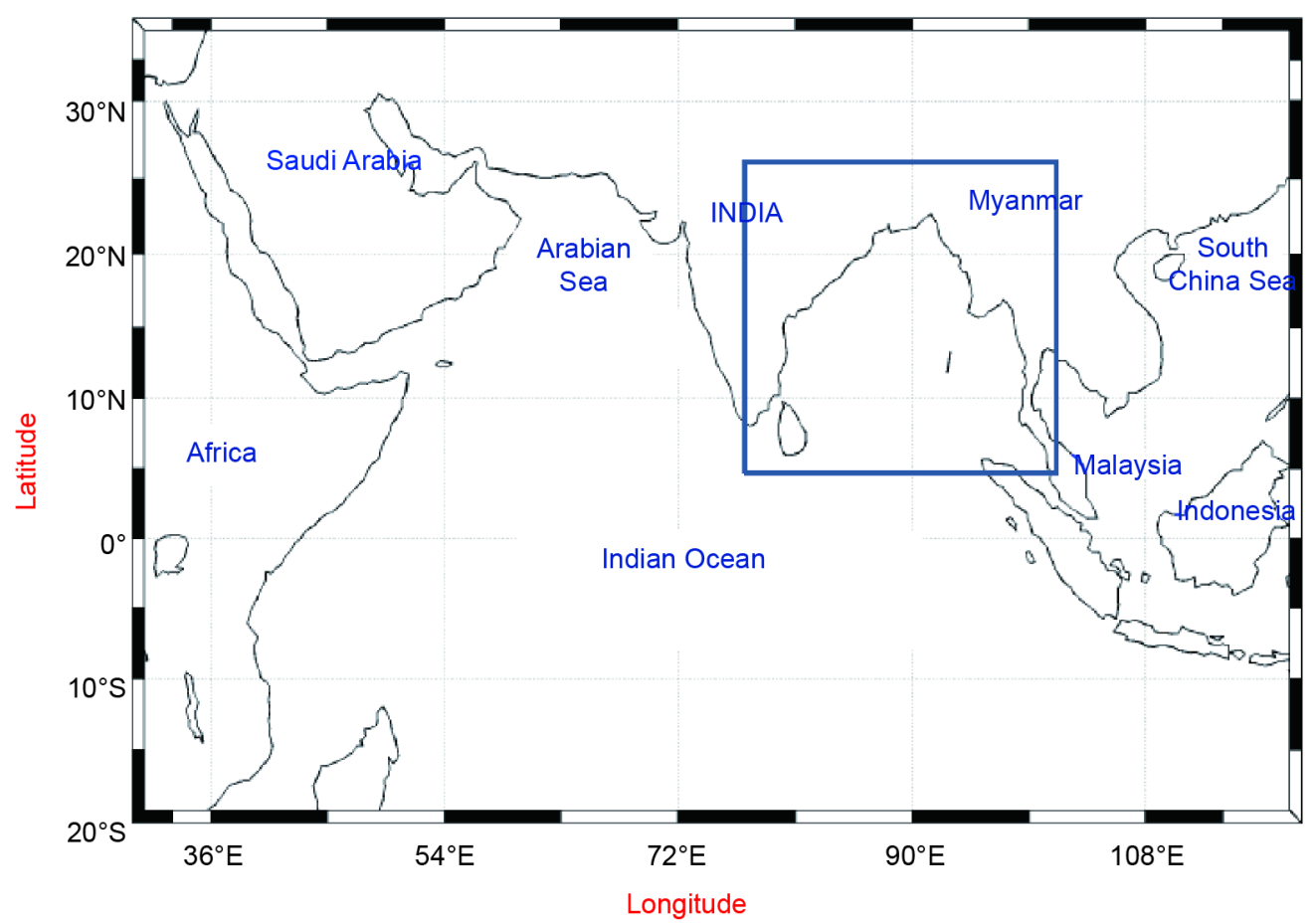

(a)

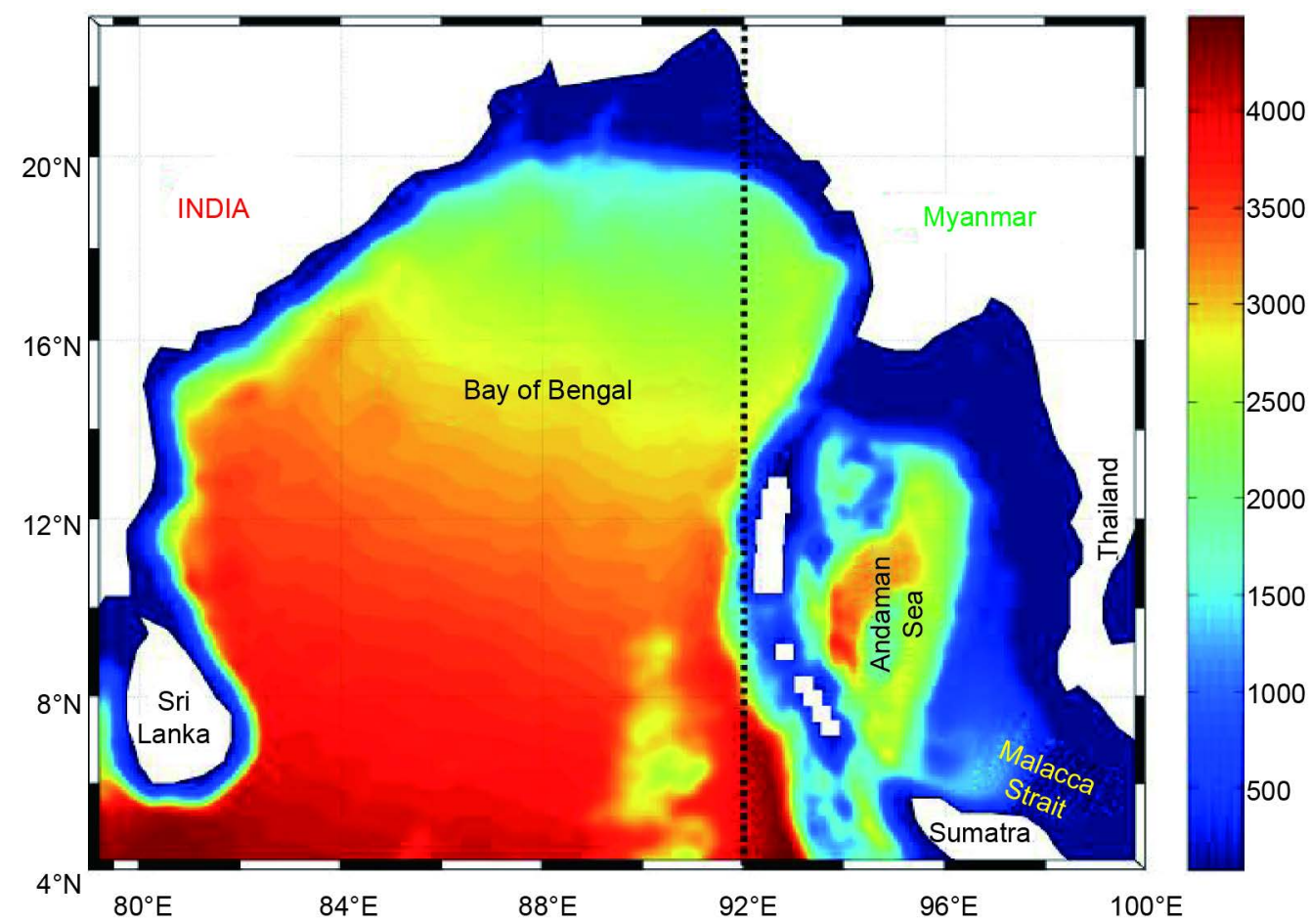

(b)

Figure 1. (a) Location of the Indian Ocean, Arabian Sea, Bay of Bengal and South China Sea. The Bay of Bengal (smaller domain) is the portion of the eastern North Indian Ocean surrounded by India, Bangladesh, Myanmar, Thailand and northern Sumatra Island. (b) Zoomed domain showing the position of the Bay of Bengal. The color map indicates the bathymetry in meters. Bathymetry clearly distinguishes the Andaman Sea from the Bay of Bengal. The vertical line demarcates the western and eastern sides of the BOB basin. 
anticyclonic gyre with a northward-flowing western boundary current (WBC) supported by the North Equatorial Current (NEC) at around $6^{\circ} \mathrm{N}$ [13] [16] [19] [27]-[31]. A cyclonic eddy on the eastern side of the northern Bay $\left(92^{\circ} \mathrm{E}, 18^{\circ} \mathrm{N}\right)$ and a flow from the South China Sea into the Bay through the Malacca Strait were also reported by [27].

During the month of June, the western boundary region of the basin is populated by a number of disorganized cyclonic and anticyclonic mesoscale eddies at the surface [13] [21] [32] fed by the Equatorial Counter Current (ECC). The Southwest Monsoon Current (SMC) flow enters the BOB between $80^{\circ} \mathrm{E}$ and $90^{\circ} \mathrm{E}$ and joins with the ECC [13] [32]-[35]. A strong cyclonic circulation around $18^{\circ} \mathrm{N}$ in the northern Bay [13] and an upwelling zone near the southeastern coast of Sri Lanka [36] are other surface circulation features in the Bay during June. A basin-scale cyclonic gyre at the subsurface during June has also been reported [21] [33].

During the month of October, the Bay displays well-defined basin-scale cyclonic surface circulation, with an organized East India Coastal Current (EICC) moving southward along the eastern coast of India [20] [27] [32]. In addition to the above circulation features, many mesoscale cyclonic or anti-cyclonic small-scale gyre and eddy features have been reported [24] [26] [32] [37] [38] but were limited to a particular year or season. A systematic description and understanding of the currents and mesoscale eddy features are required for the various applications, such as fisheries and naval operations that use high-resolution multiscale ocean state prediction models.

However, because of a scarcity of in-situ data, many mesoscale features are not well understood, and efforts to develop prediction systems are underway. Hence, the development of a high-resolution multiscale ocean prediction system is undertaken here. The first step toward developing a prediction system is to validate the system's ability to reproduce phenomenology, that is, the shapes, sizes and occurrences of major features should be reproduced in a realistic and short-term climatology-based simulation over a 15-day period. Section 2 outlines the data, model and methodology, Section 3 presents the experimental setup, Section 4 describes the simulation results with validation, and Section 5 provides a summary and conclusions.

\section{Data, Model and Methodology}

The ROMS, a free-surface, hydrostatic, primitive equation ocean model, was chosen as the numerical model in our study [39]-[41]. The model is discretized in the vertical direction over a variable topography using a stretched terrain-following coordinate known as the S-coordinate. The primitive equations are evaluated using boundaryfitted orthogonal, curvilinear coordinates on a staggered Arakawa C grid [42]. The ROMS is configured for the BOB region $\left(4^{\circ}-24^{\circ} \mathrm{N}, 79^{\circ}-100^{\circ} \mathrm{E}\right)$ with 256 grid points in the zonal direction and 249 grid points in the meridional direction, with a horizontal resolution of $10 \mathrm{~km}$. The northern, eastern and most of the western boundary are closed. The southern boundary and part of the western boundary are open. On the open boundaries, the temperature and salinity values are relaxed to match the Levitus monthly climatology. Vertical turbulent mixing is based on the K-profile parameterization (KPP) vertical mixing scheme [43]. The model consists of 32 S-coordinate layers in the vertical direction. The bottom topography is based on the Earth Topography 2-minute digital terrain model (ETOPO2) data (Figure 1(b), Table 1).

It is important to note the unique bathymetric characteristics of this region that might control the deep circulation patterns. The basin can be divided into two different zones (Figure 1(b)) east and west of $92^{\circ} \mathrm{E}$. In the western basin, the continental shelf is narrow. The depth is less than $100 \mathrm{~m}$ in the coastal region, and within a few tens of kilometers it is more than $1000 \mathrm{~m}$ deep. The Palk Strait between Sri Lanka and India is shallower than $100 \mathrm{~m}$. The exchange between the Arabian Sea and the BOB occurs through this shallow channel and is thus important in resolving the upper layers of the regional model setup for this region. The head of the BOB (north of $20^{\circ} \mathrm{N}$ ) is shallow (less than $100 \mathrm{~m}$ deep), and the depth of this part of the basin decreases southward. In the deep zone, the basin is influenced by remote effects from the Indian Ocean. The eastern part of the basin, known as the Andaman Sea $\left(\sim 93^{\circ}-98^{\circ} \mathrm{E}, 6^{\circ}-16^{\circ} \mathrm{N}\right)$, is shallow (100 m or less), except for the central part, which is more than $4000 \mathrm{~m}$ deep. The Malacca Strait, joining the Andaman Sea at the southeast $\left(99^{\circ} \mathrm{E}, 5^{\circ} \mathrm{N}\right)$, is shallow (less than $100 \mathrm{~m}$ ). There is a passage between Indonesia and Nicober Island in the deep region between the two parts of the basin.

The Levitus temperature and salinity climatology fields with $1^{\circ} \times 1^{\circ}$ [44] [45] and $0.25^{\circ} \times 0.25^{\circ}$ [46] [47] resolutions, referred to as Climo-1 and Climo-1/4, respectively, were used as the initial fields in two separate simulations. The two parts of the basin have two different characteristics, and these differences are reflected in the 
vertical Levitus temperature and salinity profiles (Figure 2). It is evident from both temperature profiles (Figure 2(a)) and salinity profiles (Figure 2(b)) that there exist two distinct water masses below $1200 \mathrm{~m}$ in depth. The mean temperature (Figure 2(c)) and salinity profiles (Figure 2(d)) indicate that these water masses belong to the two (eastern and western) parts of the basin. The water mass of the eastern side is warmer and more saline than the water mass of the western part, which is cooler and fresher. This may be due to the complex interplay among the equatorial influence, flow from the Malacca Strait, and fresh water discharge from the adjoining rivers.

The bathymetry and differences in the water masses indicate that proper vertical discretization is required to resolve this water mass system in the numerical model. To set up the vertical discretization parameter, the Brunt Vaisala frequencies $(\mathrm{N})$ of the two parts of the basin were calculated from the Levitus climatology (Figures 3(a)-3(d)). The profiles of this frequency indicate that the mixed layer stability of the western side of the basin (Figure 3(b)) is different from that of the eastern side (Figure 3(d)). To resolve this kind of structure, more levels are required in the mixed layer [48]. We chose $\theta_{s}=7.0$ and $\theta_{b}=1.0$ to enhance the vertical layers at the surface and bottom boundary layers for our numerical simulation in this basin. The vertical discretization is shown in the right panel of Figure 3(e).

\section{Numerical Experiment Setup}

First, we conducted a set of 30-day simulations initialized with two different Levitus climatologies $\left(1^{\circ} \times 1^{\circ}\right.$ and
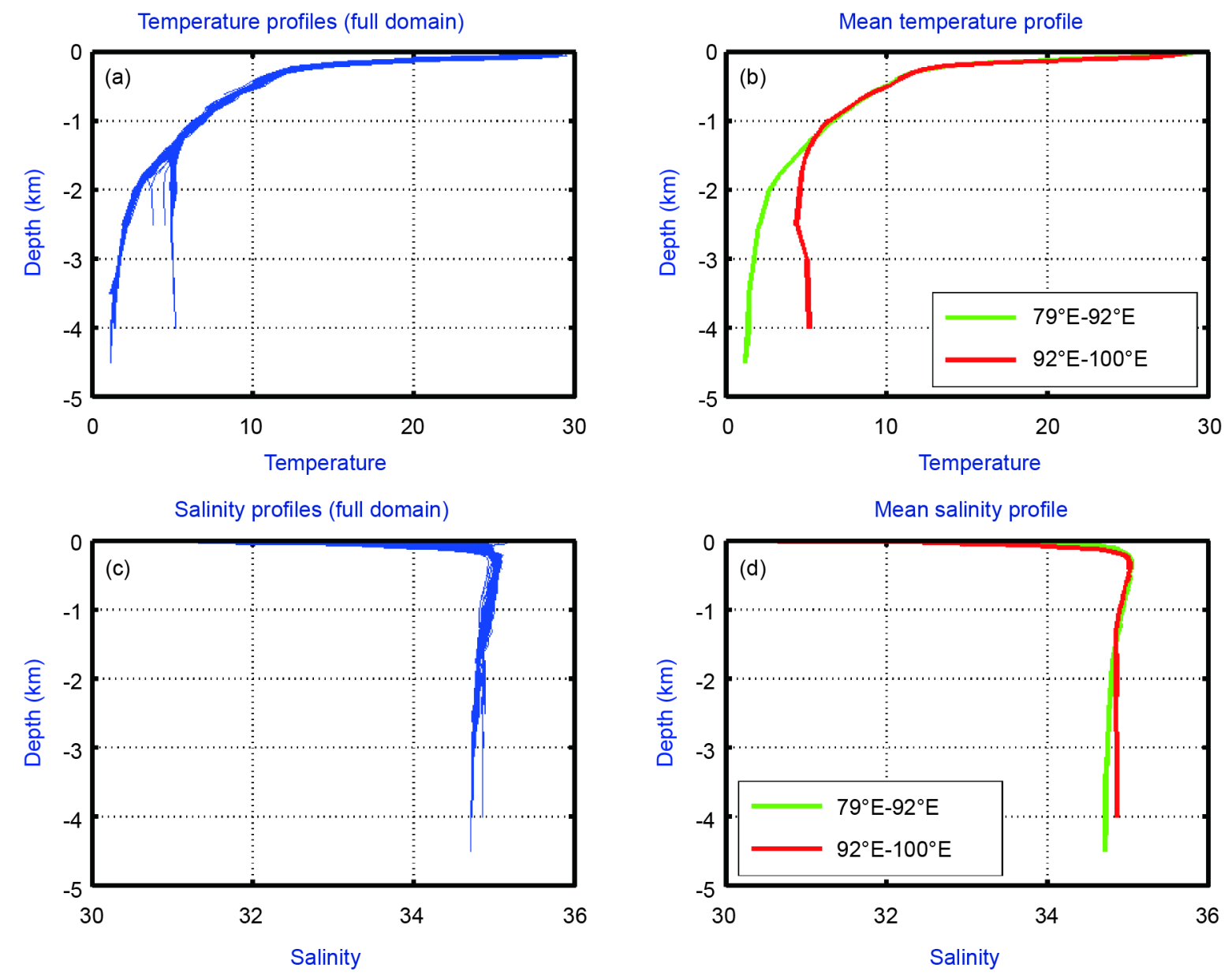

Figure 2. (a) Levitus temperature profiles for the Bay of Bengal basin. The separate profiles below $1200 \mathrm{~m}$ indicate two different water mass characteristics. (b) Mean Levitus temperature profiles for the western (green) and eastern (red) BOB. (c) Levitus vertical profiles of salinity for the entire basin. As in the temperature profiles, two different water mass characteristics below $1200 \mathrm{~m}$ are seen. (d) Mean Levitus salinity profiles for the western (green) and eastern (red) BOB. 
(a)

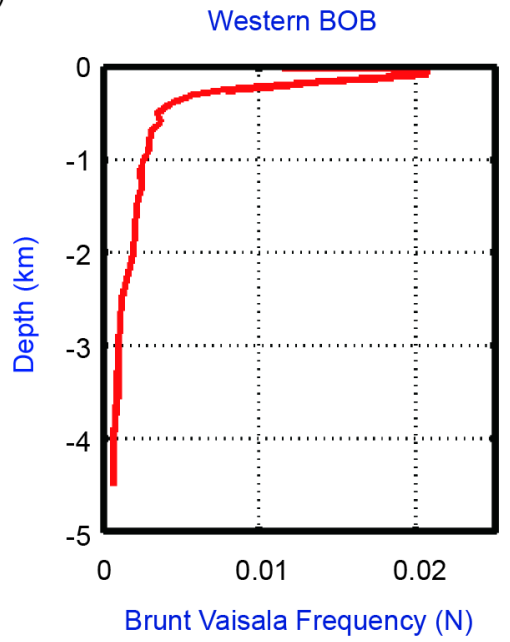

(c)

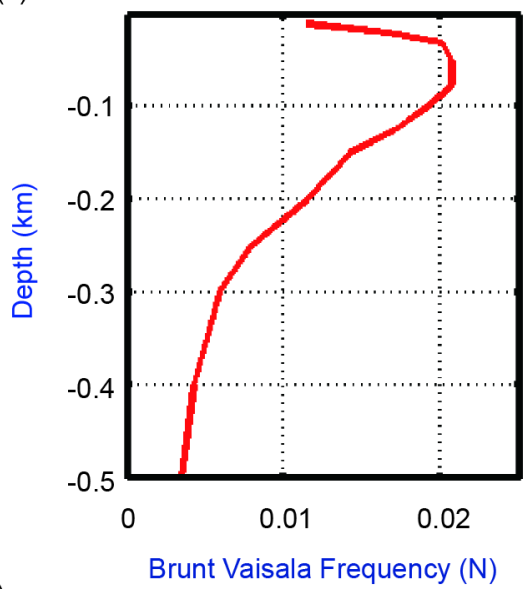

(b)

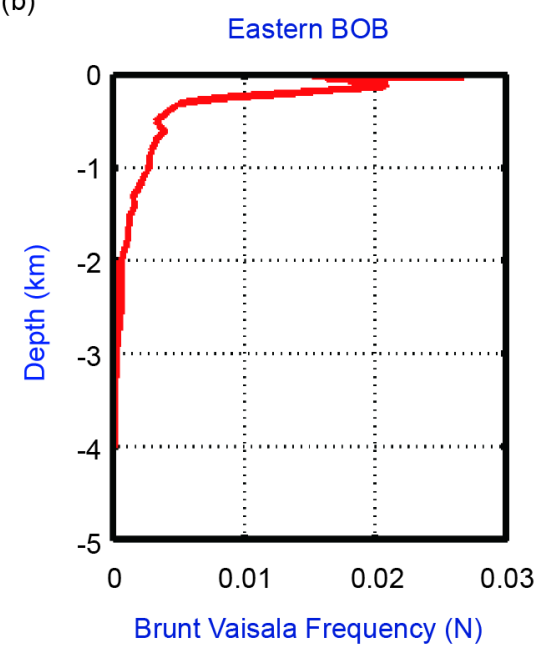

(d)

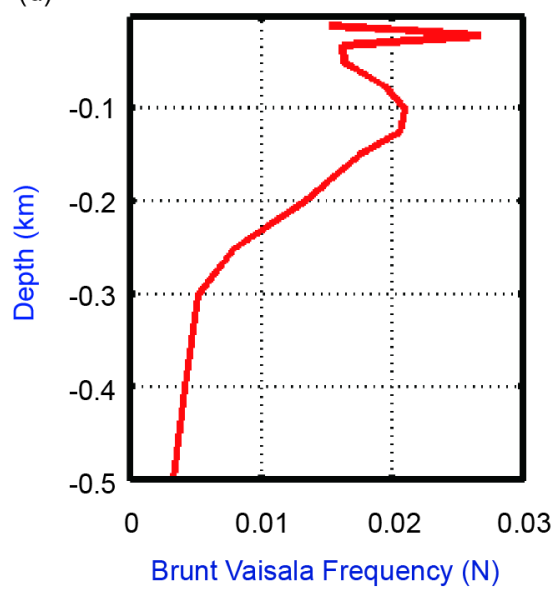

(e)

Grid Section along $8^{\circ} \mathrm{N}$

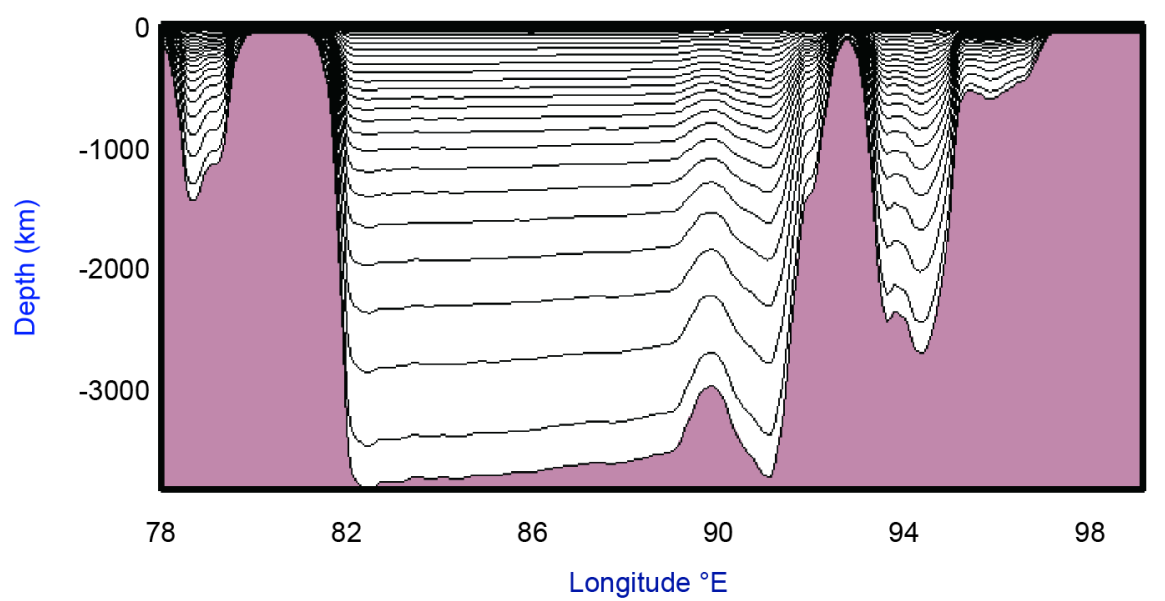

Figure 3. (a) Vertical profile of Brunt-Vaisala frequencies in the western BOB basin. (b) Vertical profile of Brunt-Vaisala frequencies on the eastern side of the basin. (c) Same profile as (a) but limited to $500 \mathrm{~m}$ depth for a clear view of mixed and thermocline layers. (d) Same as (c) but in the eastern side of the basin. These indicate that mixed-layer stability is different in the two parts of the BOB basin; to resolve this structure in the model, more levels are required in the mixed layers. (e) Vertical discretization of the S-coordinates $\left(\theta_{s}=7.0\right.$ and $\left.\theta_{b}=0.1\right)$ used in the model, showing a section along $8^{\circ} \mathrm{N}$. 
$0.25^{\circ} \times 0.25^{\circ}$ resolutions) for three different months. These experiments were: (1) Climo-1-Feb, a simulation with the $1^{\circ} \times 1^{\circ}$ Levitus February climatology; (2) Climo-1/4-Feb, a simulation with the $0.25^{\circ} \times 0.25^{\circ}$ Levitus February climatology; (3) Climo-1-Jun, a simulation with the $1^{\circ} \times 1^{\circ}$ Levitus June climatology; (4) Climo-1/ 4-Jun, a simulation with the $0.25^{\circ} \times 0.25^{\circ}$ Levitus June climatology; (5) Climo-1-Oct, a simulation with the $1^{\circ} \times$ $1^{\circ}$ Levitus October climatology; and (6) Climo-1/4-Oct, a simulation with the $0.25^{\circ} \times 0.25^{\circ}$ Levitus October climatology. Note that these simulations were carried out without any external forcing to produce a better understanding of the internal dynamics of the model in response to the different resolutions of the climatological fields.

Objective analysis (OA) [5] [49] [50] was performed to prepare the initial field on the model grid points in the BOB domain for each experiment. Compared to direct interpolation from the Levitus grid to the model grid, this multiscale OA has the advantage of keeping the dynamical feature information intact [5] [51].

The OA temperature and salinity fields on the model grid for the month of February are shown in Figures 4(a)-4(f). The surface temperature fields (Figure 4(a), Figure 4(b)) show that the upper part of the BOB (north of $16^{\circ} \mathrm{N}$ ) is colder than the southern part of the basin. The western coast of the basin is also colder than the eastern part. In addition to the two upwelling zones seen in Climo-1 (Figure 4(a)), there are more features observed in Climo-1/4 (Figure 4(b)). The surface salinity is lower on the eastern side of a line from the northern tip of Sumatra to the point where $18^{\circ} \mathrm{N}$ intersects the eastern coast of India, with minimum salinity at the head of the Bay (Figure 4(c), Figure 4(d)). As with the surface, many mesoscale temperature (Figure 4(e)) and salinity (Figure 4(f)) features are observed in the subsurface in Climo-1/4.

Figures 5(a)-5(f) show the OA temperature and salinity fields for the month of June. The small-scale features of the cold and warm regions can be seen in Figure 5(a), Figure 5(b). The surface features of Climo-1/4 (Figure 5(b)) are distinct from those of Climo-1 (Figure 5(a)). The mesoscale features and the penetration of high- salinity water are evident from the salinity plots (Figure 5(c), Figure 5(d)). The northeastern side is less saline than the other side of the basin in both of the data sets. This lower salinity reflects the influence of freshwater discharge from the rivers surrounding the basin. The less saline zone near the Visakhapatnam coast is seen in Climo-1/4 (Figure 5(d)) but not in Climo-1 (Figure 5(c)). Distinct upwelling and downwelling zones are present in the subsurface in Climo-1/4 (Figure 5(e)) only.

The OA temperature and salinity fields for the month of October are presented in Figures 6(a)-6(f). The surface isotherms in the southern part of the BOB are smooth and oriented to the northeast in Climo-1 (Figure 6(a)). A dual-core warm region is present in the northern part of the Bay. The upwelling region off of the coast of India around $16^{\circ} \mathrm{N}$ is stronger in Climo-1 (Figure 6(a)) than in Climo-1/4 (Figure 6(b)). Although the isotherms are not smooth in Climo-1/4 (Figure 6(b)), it shows many more mesoscale features than Climo-1 (Figure 6(a)). Surface salinity is low in the northern part of the $\mathrm{BOB}$ and along the eastern and western shores of the BOB above $15^{\circ} \mathrm{N}$ (Figure 6(c), Figure 6(d)). The warm and cold features are clear at a depth of $100 \mathrm{~m}$. The warm down welling regions and cold upwelling regions are distinctly visible in Climo-1/4 (Figure 6(e)). The salinity at the subsurface is lower on the eastern side (Andaman Sea) than on the western side of the BOB (Figure 6(f)).

The warm and cold features in the temperature fields, as well as the high- and low-salinity regions in the salinity fields discussed above, indicate that more small-scale features are captured in Climo-1/4 than Climo-1.

\section{Simulation Set-Up and Results}

Short-term climatological simulations require three-dimensional specifications of the initial temperature, salinity and current $(T, S, u$ and $v$ ) fields. However, the standard practice in basin-scale numerical modeling exercises is to specify only $T$ and $S$ with zero velocity [2] [52], which requires the models to develop the inertia fields in a spin-up time that may range from 1 to 10 years [51]. Our goal was to develop a system for short-term synoptic forecasting for applications in which users cannot afford to run models for a long period of spin-up time. Thus, specifying the best possible velocity field in addition to the mass ( $\mathrm{t}$ and $\mathrm{s}$ ) field becomes mandatory in synoptic short-term simulations. [53] [54] have discussed the barotropic-adjustments to the internal dynamics and wind forcing for synoptic forecasting with ROMS. The strategy for setting ROMS in the BOB region was carried out using initial climatological T-S fields following [2], with the addition of geostrophic velocity as the initial conditions for the velocities, which were balanced with the initial T-S fields. The initial geostrophic velocity was computed from the temperature and salinity provided by the OA methodology [5] using a simple dynamic height computation (with a prescribed level of no motion) mentioned above. 

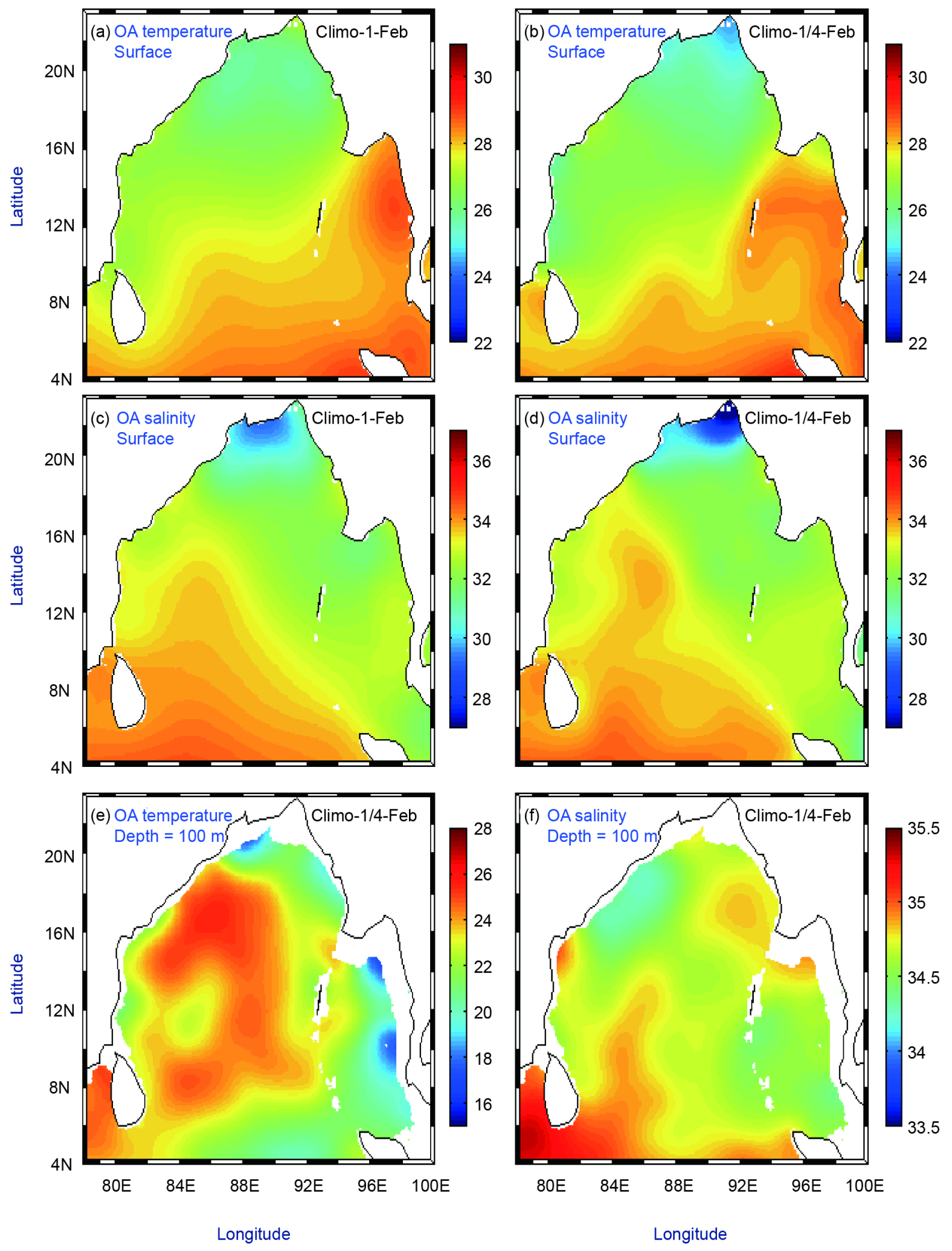

Figure 4. Initial model field for the month of February derived from the following objectively analyzed fields: (a) surface temperature from Climo-1; (b) surface temperature from Climo-1/4; (c) surface salinity from Climo-1; (d) surface salinity from Climo-1/4; (e) temperature at $100 \mathrm{~m}$ depth from Climo-1; and (f) salinity at $100 \mathrm{~m}$ depth from Climo-1/4. 

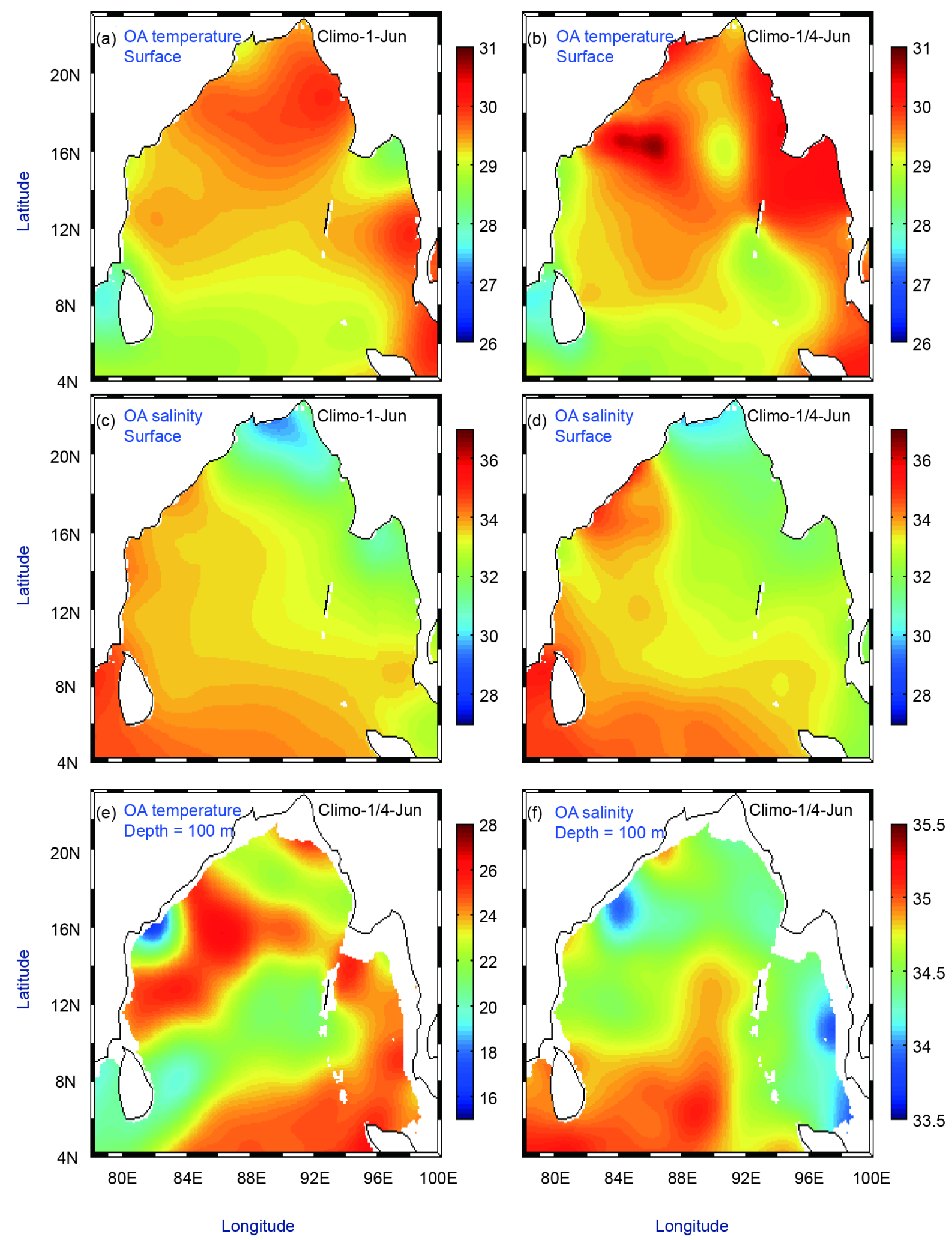

Figure 5. Initial model field for the month of June derived from the following objectively analyzed fields: (a) surface temperature from Climo-1; (b) surface temperature from Climo-1/4; (c) surface salinity from Climo-1; (d) surface salinity from Climo-1/4; (e) temperature at $100 \mathrm{~m}$ depth from Climo-1; and (f) salinity at $100 \mathrm{~m}$ depth from Climo-1/4. 

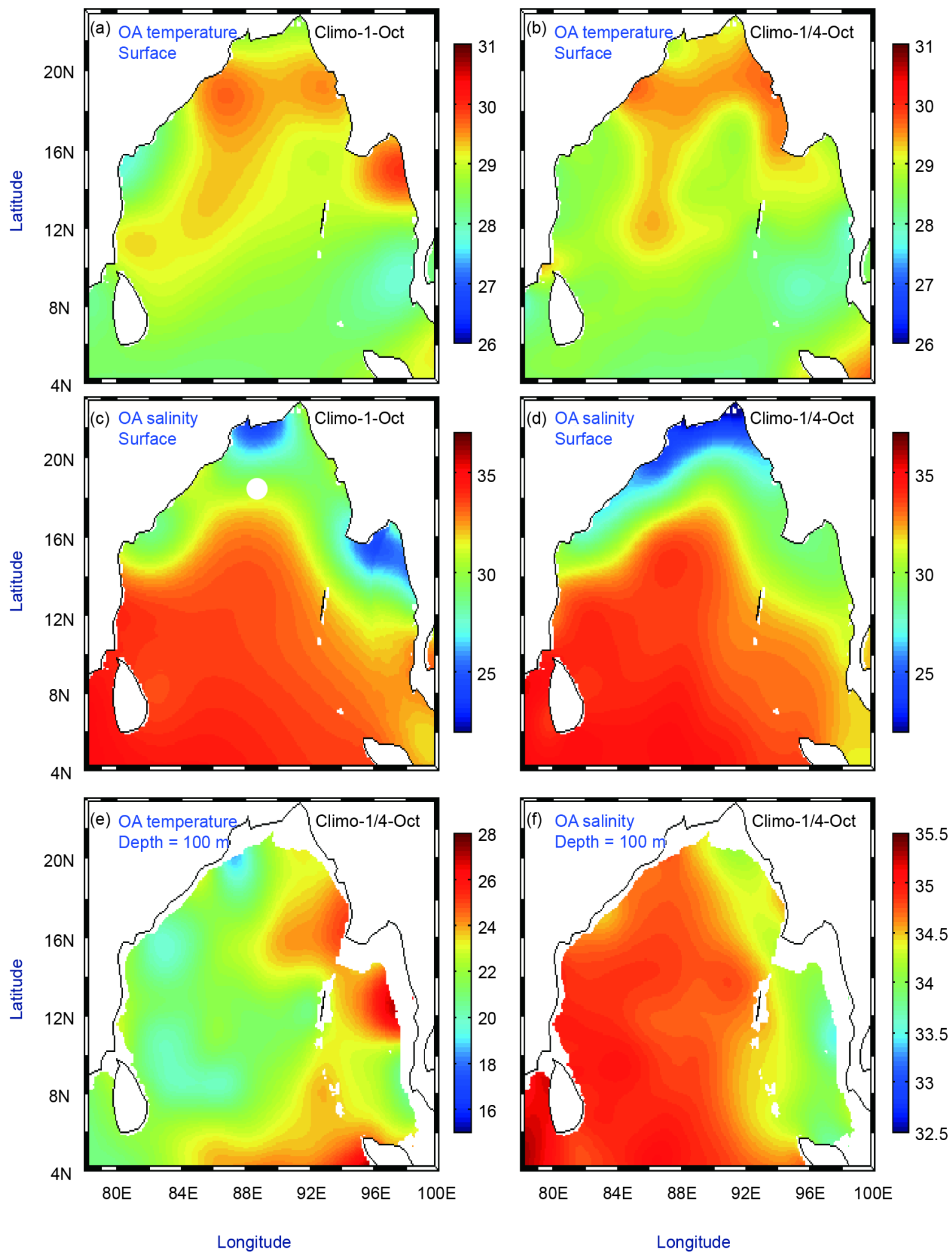

Figure 6. Initial model field for the month of October derived from the following objectively analyzed fields: (a) surface temperature from Climo-1; (b) surface temperature from Climo-1/4; (c) surface salinity from Climo-1; (d) surface salinity from Climo-1/4; (e) temperature at $100 \mathrm{~m}$ depth from Climo-1; and (f) salinity at $100 \mathrm{~m}$ depth from Climo-1/4. 


\subsection{Comparison of $1^{\circ} \times 1^{\circ}$ and $0.25^{\circ} \times 0.25^{\circ}$ Resolution Climatologies}

The temporal evolution of the kinetic energy in the different simulation experiments explained above is shown in Figure 7. The simulation with $1^{\circ}$ resolution data shows the volume-averaged kinetic energy slowly becoming stable after two days of model integration, but the simulations with $0.25^{\circ}$ resolution data show that the volume-averaged kinetic energy is always higher than in the simulations with $1^{\circ}$ resolution data. The larger kinetic energy for the $0.25^{\circ}$ resolution data may arise from the greater number of eddies present due to the higher resolution. This also indicates that $0.25^{\circ}$ data will allow the high-resolution model to be more eddy-permitting than $1^{\circ}$ data in this region.

Figures 8-12 show comparisons of the respective surface circulations of the above experiments. Figures 8(a)-8(c) show the evolved fields for February, June and October, respectively, after 15 days of simulation with Climo-1. Figures 9(a)-9(d) show days 6, 9, 12 and 15, respectively, of February Climo-1/4. The transports through the Palk Strait (across 9N), Malacca Strait (across a section from 98E, 5N to 100E, 7N) and through WBC (Feb/June) or EICC (Oct) at 12N (across 80 - 82E) are listed in Table 2 for both simulations on days 5 and 15 of all three 1-month simulations. The maximum simulated velocities in the Malacca Strait and the WBC/ EICC flows on similar months/days are also presented in Table 3. Comparing Figure 8(a) with Figure 9(d), and the transport/velocity magnitudes in Table 2 and Table 3, it is evident that, in Climo-1/4, the WBC is continuous and stronger (10.64 Sv versus 7.35 Sv), the northwestward flow along the eastern coast of Sri Lanka is more well developed and the flow through the Malacca Strait is stronger (3.2 Sv versus 2.39 Sv) and better resolved than in Climo-1. Similar comparisons can be made between Figure 8(b) and Figure 10(d) and between Figure 8(c) and Figure 11(d). Figures 8(d)-8(f) show the 15-day evolution of Climo-1 at $100 \mathrm{~m}$. Although there are hints of boundary currents and eddies, the Climo-1/4 simulations (discussed later in section 4.2.2) resolved these better. Eddies formed during different simulations and their observational evidence, if any, from

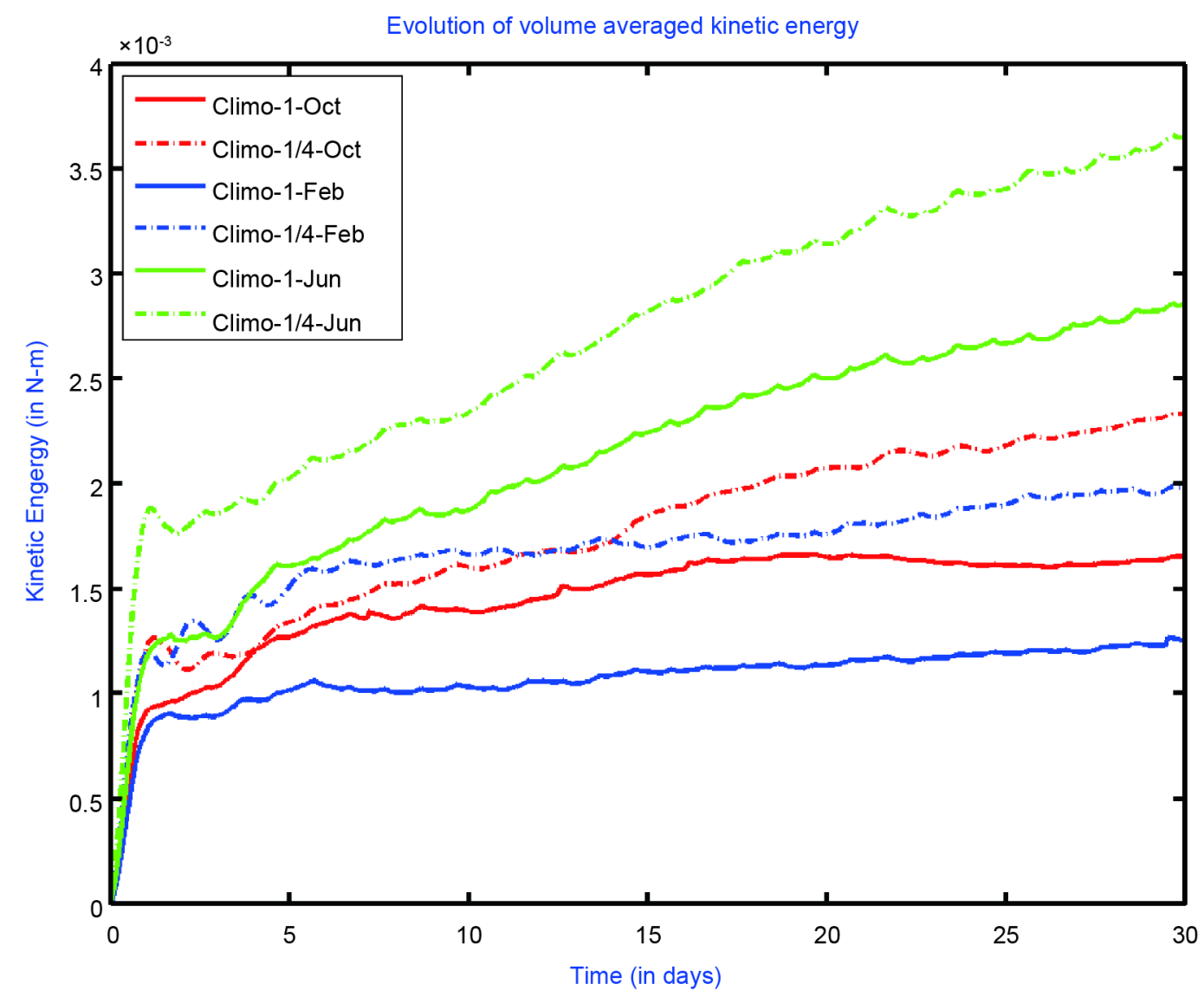

Figure 7. Time evolution of the volume-averaged kinetic energy of the climatology-based model experiments. Figure shows the quasi-equilibrium condition after five days of model integration. 

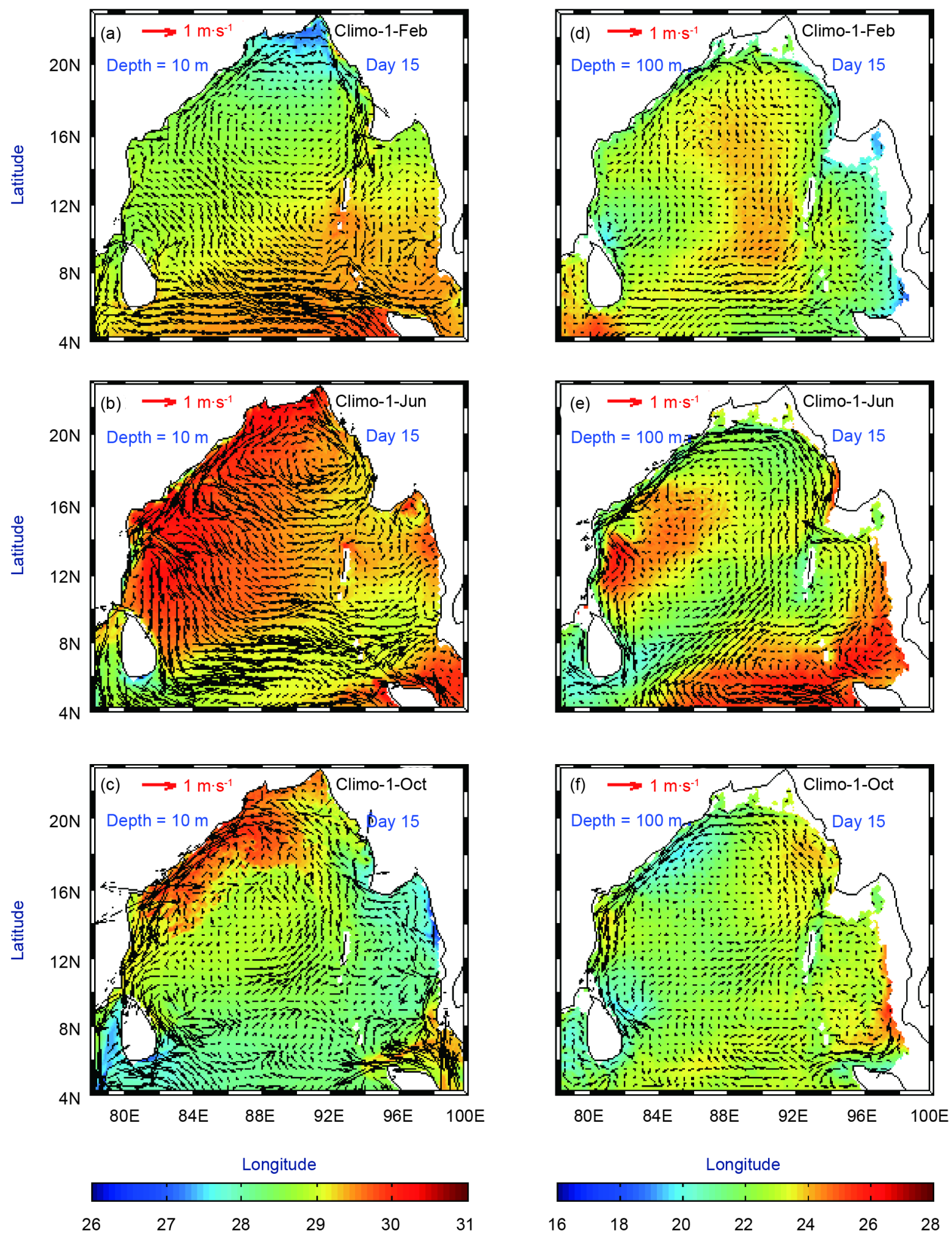

Figure 8. Model-simulated currents (vectors) with temperature (colored) for the day 15 simulation at: (a) $10 \mathrm{~m}$ depth of the Climo-1-Feb experiment; (b) $10 \mathrm{~m}$ depth of the Climo-1-Jun experiment; (c) $10 \mathrm{~m}$ depth of the Climo-1-Oct experiment; (d) $100 \mathrm{~m}$ depth of the Climo-1-Feb experiment; (e) $100 \mathrm{~m}$ depth of the Climo-1-Jun experiment; and (f) $100 \mathrm{~m}$ depth of the Climo-1-Oct experiment. 

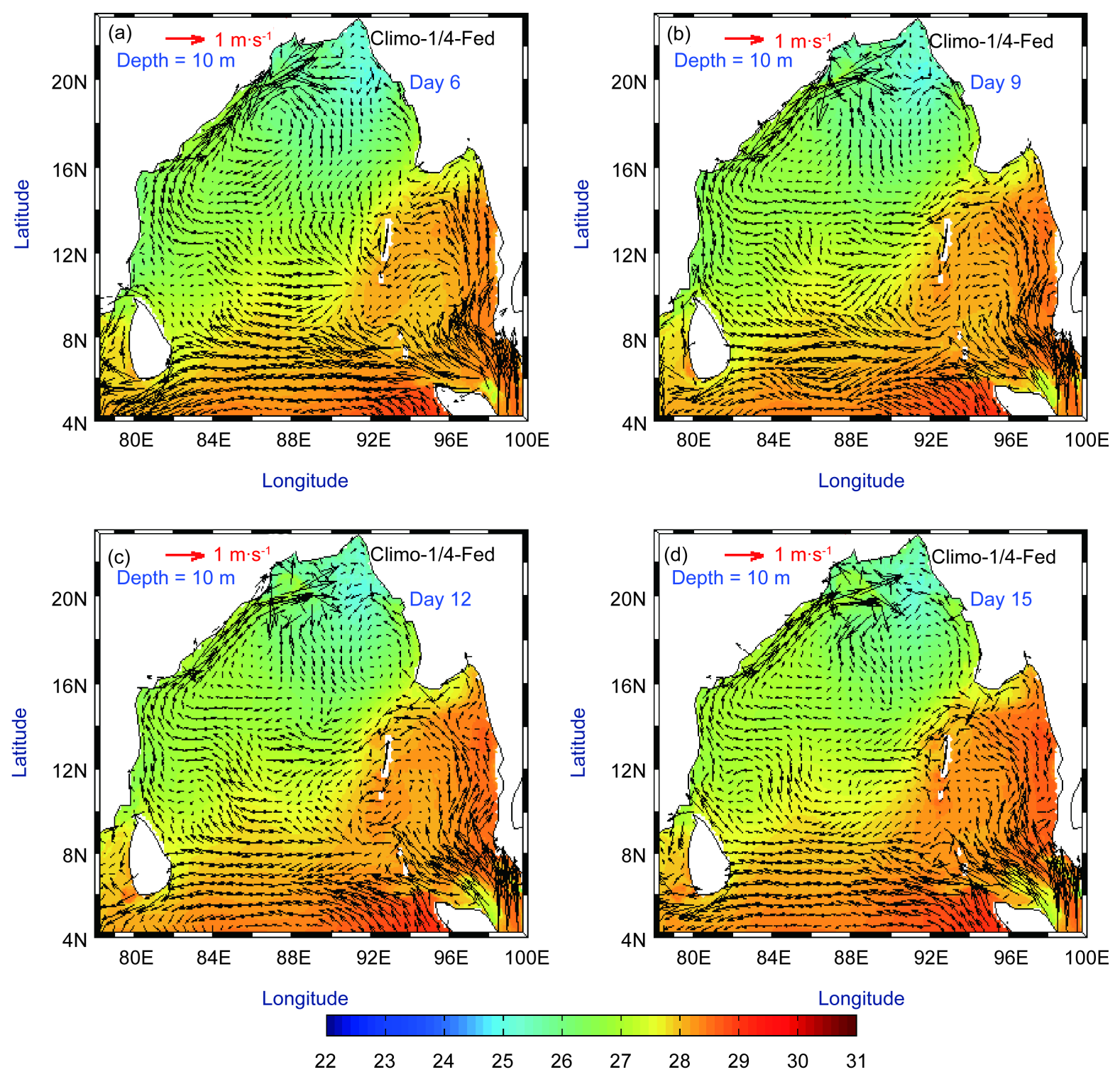

Figure 9. Model-simulated currents (vectors) with temperature (colored) for the Climo-1/4-Feb experiment at $10 \mathrm{~m}$ depth for: (a) day 6; (b) day 9; (c) day 12; and (d) day 15 of the integration.

other studies are listed in Table 4. It is evident that the formation of a number of eddies in the Climo-1/4 simulation is in reasonable agreement with observation (Table 4). Because the quarter-degree resolution results seemed more realistic in terms of the strength of flows and occurrence of eddies, our discussions are confined only to the quarter-degree simulations (Climo-1/4-Feb, Climo-1/4-Jun and Climo-1/4-Oct) in the following sections.

\subsection{Simulated Circulation $\left(1 / 4^{\circ}\right)$}

In this section, we describe the major circulation features resolved by the climatology-based simulations in the surface, subsurface and deep layers. For each simulation, the fields over 15 days are described because these are the time scales of interest for the development of a first-order synoptic forecast system.

\subsubsection{Circulation}

The climatology-based simulation of the evolution of surface currents in February (Climo-1/4-Feb) is shown in 

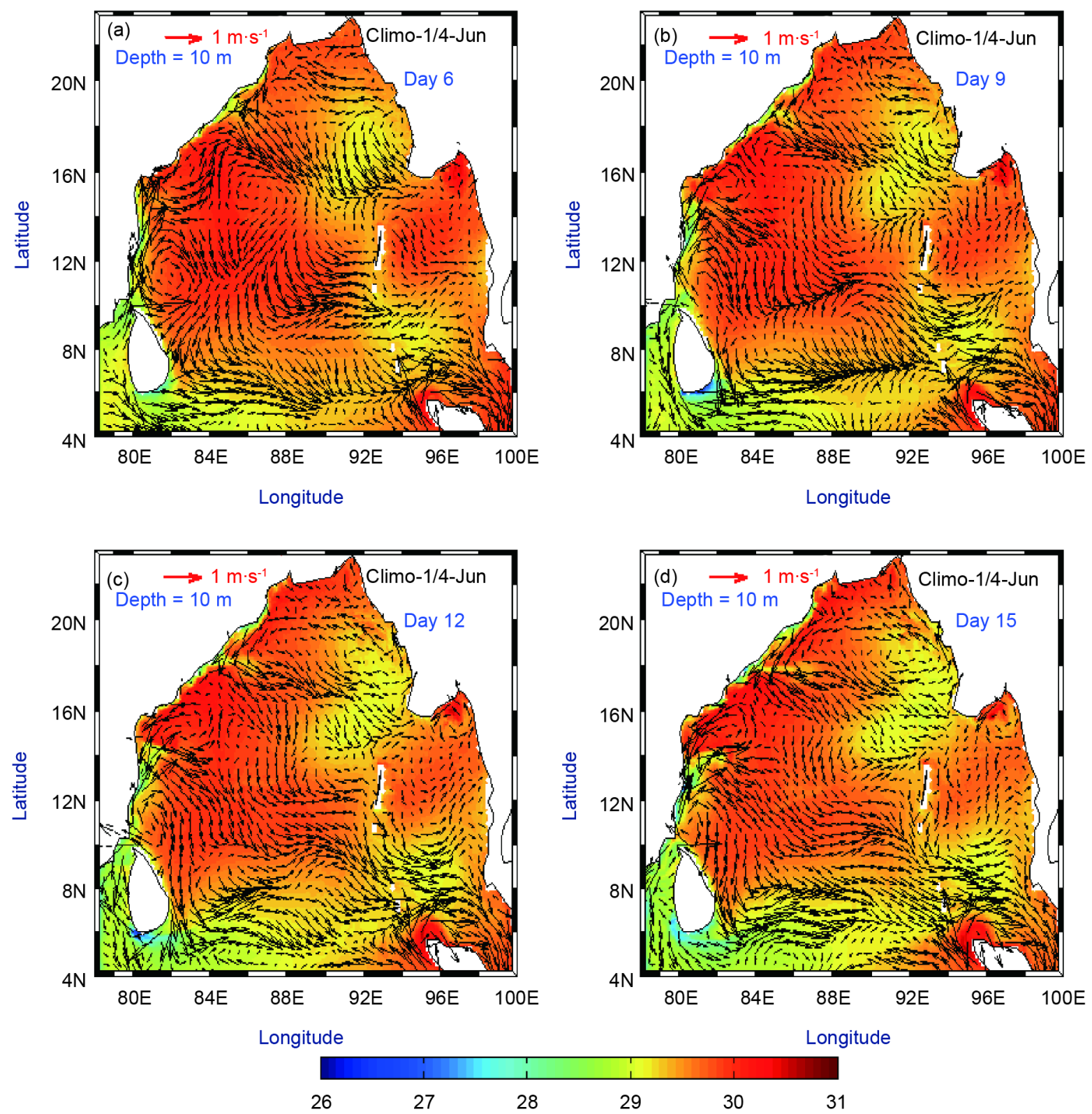

Figure 10. Model-simulated currents (vectors) with temperature (colored) for the Climo-1/4-Jun experiment at $10 \mathrm{~m}$ depth for: (a) day 6; (b) day 9; (c) day 12; and (d) day 15 of the integration.

Figures 9(a)-9(d) for days 6, 9, 12 and 15, respectively. The WBC becomes a continuous, steady flow from $10^{\circ} \mathrm{N}$ to $20^{\circ} \mathrm{N}$ by day 9 (Figures 9(b)-9(d)). Observational evidence for the existence of this current system is available in earlier studies [19] [27]-[31]. Within 12 days of integration, the overall surface circulation is more organized and stable (Figure 9(c)). Note that the transport and velocity amplitudes tend to stabilize by day 15 (see Table 2 and Table 3). The anticyclonic gyre and eddies are well organized by day 15 of the model simulation (Figure 9(d)). The temperature contrast between the colder northwestern basin and the warmer southwestern basin is maintained during the 15 days of simulation (Figure 9(d)). A similar temperature contrast was also reported by [19]. Strong currents along the Sumatra coast and through the Malacca Strait bring warm waters into the BOB and Andaman Sea. This Malacca Strait flow was previously reported to originate from the South China Sea in a ship-drifts study by [27]. The incoming flow through the Malacca Strait flows northward along the eastern boundary of the basin up to $15^{\circ} \mathrm{N}$ and turns around the Andaman Islands to join two large anticyclonic 

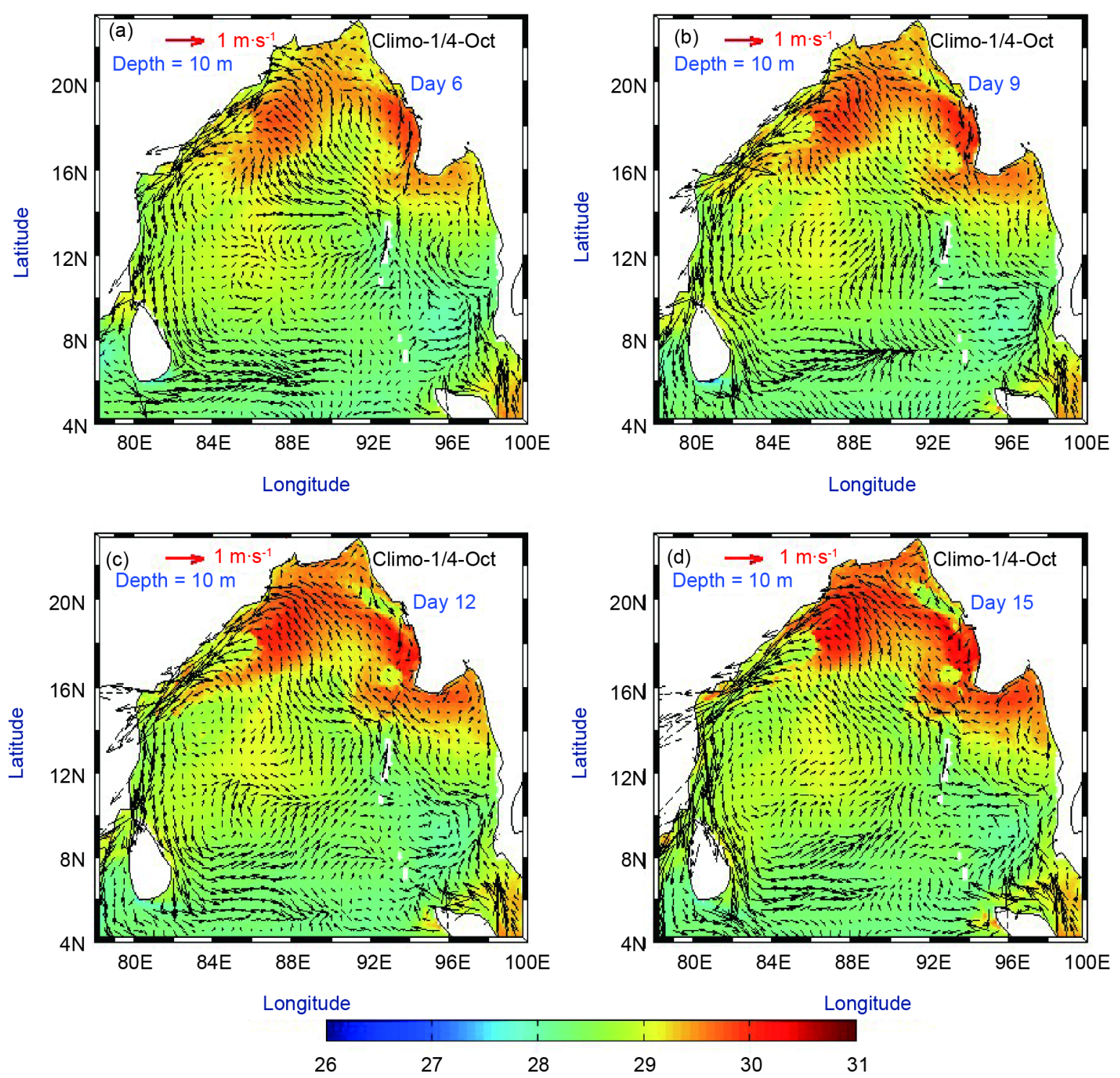

Figure 11. Model-simulated currents (vectors) with temperature (colored) for the Climo-1/4-Oct experiment at $10 \mathrm{~m}$ depth for: (a) day 6; (b) day 9; (c) day 12; and (d) day 15 of the integration.

gyres set up over the western basin. A portion of this flow bifurcates at around $15-16^{\circ} \mathrm{N}$, flows along the Myanmar coast, and becomes part of a large cyclonic gyre.

The simulation shows that the NEC is stronger during February (Figure 9(d)) and bifurcates at $8^{\circ} \mathrm{N}$, with one branch flowing northward along the east coast of Sri Lanka and another branch moving southward around the southern tip of Sri Lanka. Furthermore, the northward branch bifurcates near the northern tip of Sri Lanka, with one part merging with the northward WBC and one part flowing southward through the Palk Strait. The WBC brings warm water to the head of the BOB, where it mixes with cold water in this region and bifurcates to form two eddies-CE-Feb $1\left(87^{\circ} \mathrm{E}, 21^{\circ} \mathrm{N}\right)$ on the inshore side and ACE-Feb1 $\left(87.5^{\circ} \mathrm{E}, 19.5^{\circ} \mathrm{N}\right)$ on the offshore side of the WBC. One cyclonic eddy near the eastern side of the head of the BOB-CE-Feb2 $\left(91^{\circ} \mathrm{E}, 21.5^{\circ} \mathrm{N}\right)$ - was observed in this simulation (Figure 9(d)). The vertical extent of these eddies are on the order of $50-70 \mathrm{~m}$. Table 4 lists the simulated sizes and depths of all eddies. A cold core cyclonic eddy-CE-Feb3 $\left(92^{\circ} \mathrm{E}, 18^{\circ} \mathrm{N}\right)$ - was also observed on the eastern side of the head of the BOB during day 15 of model integration. This was also reported by [27]. A small cyclonic eddy-CE-Feb4 $\left(97^{\circ} \mathrm{E}, 16^{\circ} \mathrm{N}\right)$ - was observed at the southern corner of the Myanmar coast in the simulation (Figure 9(d)). At the head of the Bay during February, the cyclonic-anticyclonic pair 

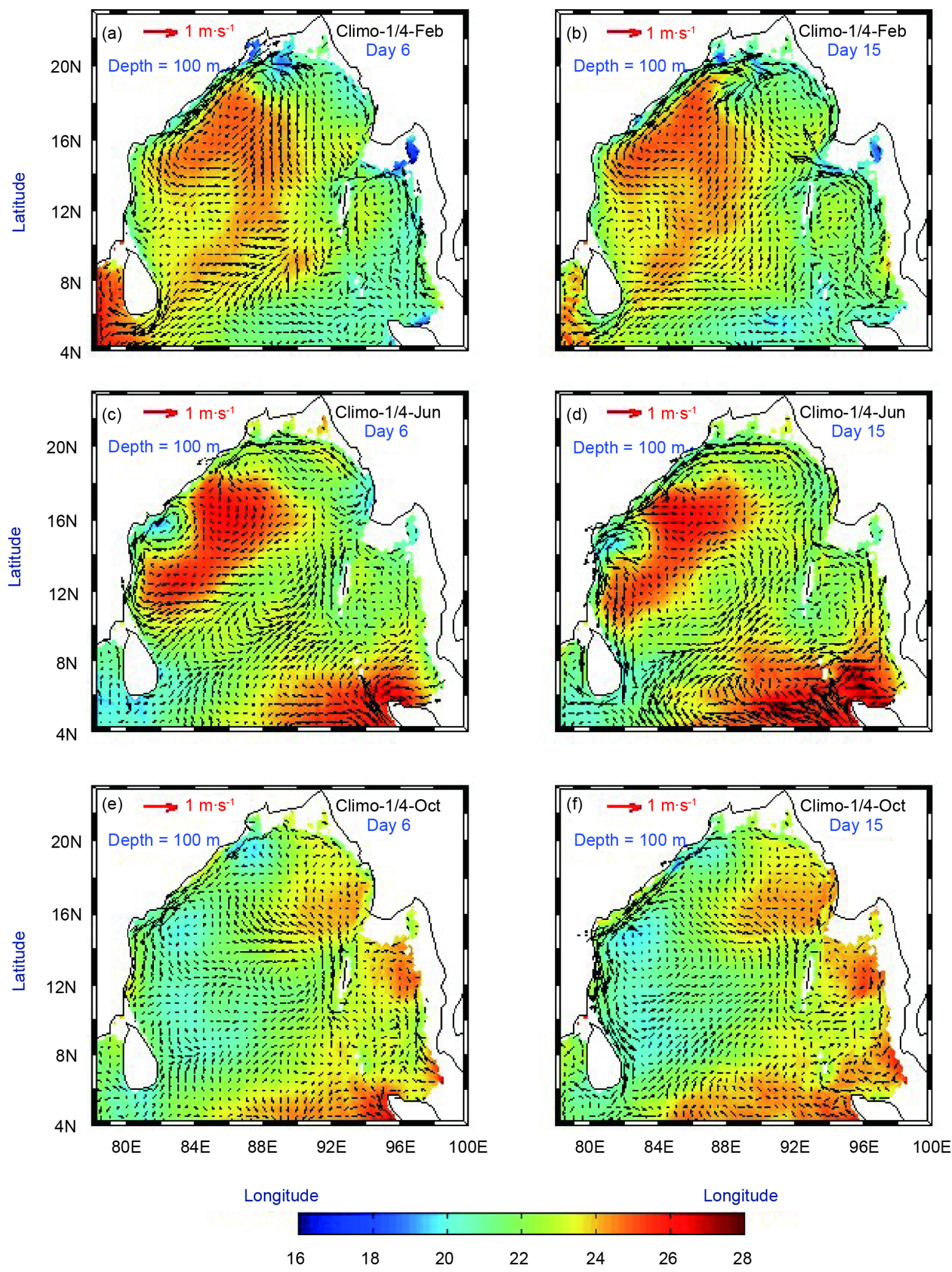

Figure 12. Model-simulated currents (vectors) with temperature (colored) at $100 \mathrm{~m}$ depth for: (a) day 6 of the Climo-1/4-Feb experiment; (b) day 15 of the Climo-1/4-Feb experiment; (c) day 6 of the Climo-1/4-Jun experiment; (d) day 15 of the Climo-1/4-Jun experiment; (e) day 6 of the Climo-1/4-Oct experiment; and (f) day 15 of the Climo-1/4-Jun experiment. 
Table 1. Numerical parameters used in the ROMS model simulations.

\begin{tabular}{|c|c|}
\hline Model Parameter & Value \\
\hline Depth & $0-5500 \mathrm{~m}$ \\
\hline S-coordinate surface control parameter & 7 \\
\hline S-coordinate bottom control parameter & 0.1 \\
\hline Thermocline depth stretching parameter & $10 \mathrm{~m}$ \\
\hline Mean density & $1025 \mathrm{~kg} \cdot \mathrm{m}^{-3}$ \\
\hline Lateral harmonic constant mixing coefficient for momentum & $4000 \mathrm{~m}^{2} \cdot \sec ^{-1}$ \\
\hline Lateral biharmonic constant mixing coefficient for momentum & $100 \mathrm{~m}^{4} \cdot \sec ^{-1}$ \\
\hline Lateral harmonic constant mixing coefficient for tracer & $1000 \mathrm{~m}^{2} \cdot \mathrm{sec}^{-1}$ \\
\hline Linear bottom drag coefficient & $10^{-4} \mathrm{~m} \cdot \mathrm{sec}^{-1}$ \\
\hline Quadratic bottom drag coefficient & $0 \mathrm{~m} \cdot \mathrm{sec}^{-1}$ \\
\hline Slipperiness variable & 1 (no slip) \\
\hline Sponge layer thickness & $105 \mathrm{~m}$ \\
\hline Viscosity in sponge layer & $800 \mathrm{~m}^{2} \cdot \mathrm{sec}^{-1}$ \\
\hline
\end{tabular}

Table 2. Transport values through selected sections for Climo-1 and Climo-1/4 simulations.

\begin{tabular}{|c|c|c|c|c|c|c|c|}
\hline \multirow{3}{*}{ Sections } & & \multicolumn{6}{|c|}{ Transport values (Sv) from the experiments } \\
\hline & & \multicolumn{2}{|c|}{ Feb } & \multicolumn{2}{|c|}{ Jun } & \multicolumn{2}{|c|}{ Oct } \\
\hline & & Day 6 & Day 15 & Day 6 & Day 15 & Day 6 & Day 15 \\
\hline \multirow{2}{*}{ Palk Strait, $9^{\circ} \mathrm{N}$} & Climo-1 & -0.31 & -0.46 & -0.004 & -0.02 & -0.19 & -0.54 \\
\hline & Climo-1/4 & -0.49 & -0.52 & -0.01 & -0.03 & -0.23 & -0.67 \\
\hline \multirow{2}{*}{$\begin{array}{c}\text { Malacca Strait } \\
98^{\circ} \mathrm{E}, 5^{\circ} \mathrm{N} \text { to } 100^{\circ} \mathrm{E}, 7^{\circ} \mathrm{N}\end{array}$} & Climo-1 & 1.18 & 2.39 & -1.89 & -2.45 & 0.98 & 1.67 \\
\hline & Climo-1/4 & 2.67 & 3.26 & -2.43 & -3.07 & 1.33 & 2.01 \\
\hline \multirow{2}{*}{$\begin{array}{c}80^{\circ} \mathrm{E}-82^{\circ} \mathrm{E}, 12^{\circ} \mathrm{N} \\
\text { WBC/EICC }\end{array}$} & Climo-1 & WBC 5.28 & WBC 7.35 & WBC 7.84 & WBC 10.19 & EICC -12.28 & EICC -18.17 \\
\hline & Climo-1/4 & WBC 8.77 & WBC 10.64 & WBC 9.01 & WBC 12.23 & EICC -15.23 & EICC -23.12 \\
\hline
\end{tabular}

* -ve sign indicates outflow or southward and +ve sign indicates inflow or northward.

Table 3. Maximum velocities through selected sections for Climo-1 and Climo-1/4 simulations.

\begin{tabular}{|c|c|c|c|c|c|c|c|}
\hline \multirow{3}{*}{\multicolumn{2}{|c|}{ Region }} & \multicolumn{6}{|c|}{ Maximum velocity $(\mathrm{m} / \mathrm{s})$ from the experiments } \\
\hline & & \multicolumn{2}{|c|}{ Feb } & \multicolumn{2}{|c|}{ Jun } & \multicolumn{2}{|c|}{ Oct } \\
\hline & & Day 6 & Day 15 & Day 6 & Day 15 & Day 6 & Day 15 \\
\hline \multirow{2}{*}{ Malacca Strait } & Climo-1 & 0.15 & 0.23 & -0.28 & -0.45 & 0.79 & 0.94 \\
\hline & Climo-1/4 & 1.44 & 1.52 & -0.58 & -0.63 & 0.76 & 1.08 \\
\hline \multirow{2}{*}{ WBC/EICC } & Climo-1 & 0.38 & 0.45 & 0.98 & 1.04 & -1.09 & -1.42 \\
\hline & Climo-1/4 & 1.48 & 1.61 & 1.02 & 1.16 & -1.32 & -1.58 \\
\hline
\end{tabular}

* +ve sign indicates northward and -ve sign indicates southward. 
Table 4. List of eddies formed in the BOB in the numerical simulations.

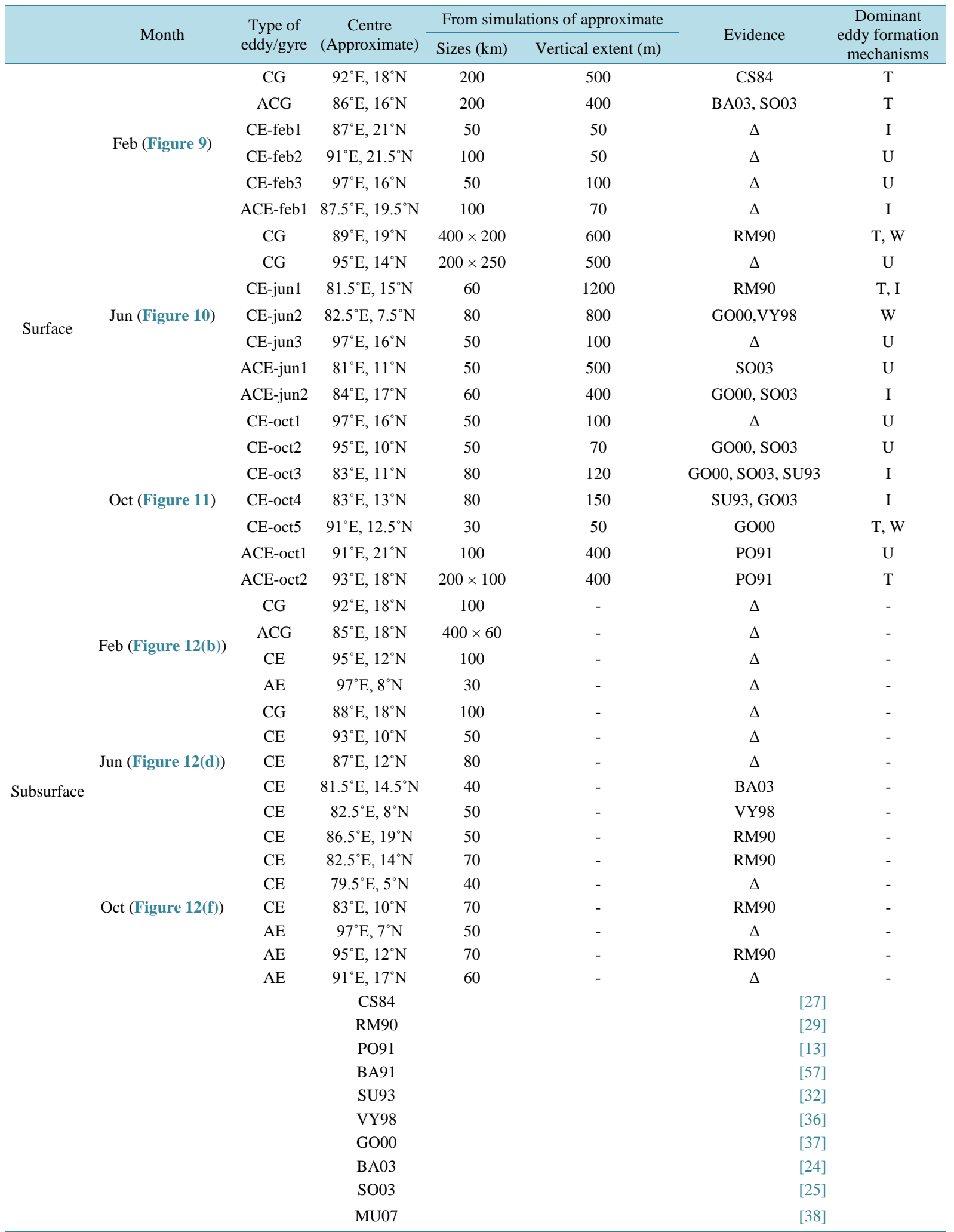

CE: Cyclonic Eddy; CG: Cyclonic Gyre; ACE: Anticyclonic Eddy; ACG: Anticyclonic Gyre; T: Topography; W: Wind stress curl; I: Instability; U: unknown; $\Delta$ : Observational evidence of these eddies are awaited. Remarks: There are differences in the location of the eddy/gyre centers between the model results and observations. 
from the WBC, the cyclonic gyre and the small cyclonic eddy constituted a very active mesoscale confluence zone (Figure 9(d)). The dynamical mechanism responsible for the occurrences of these eddies has not been fully determined; however, we have indicated a few possibilities (topography, instabilities, wind-curl driving) based on some of the previous work of [38] and others listed in Table 4.

During June (Climo-1/4-Jun), when the southwest monsoon starts, the surface circulation changes due to the changing winds. The summer surface water is warmer throughout the basin (Figure 10) than in the winter (February) simulation (Figure 9). The features are more organized on day 12 of model integration (Figure 10(c), Figure 10(d)) than on days 6 and 9 (Figure 10(a), Figure 10(b)). Eddies, gyres and the Southwest Monsoon Current (SMC) are prominent on day 15 of the model simulation (Figure 10(d)). Three cyclonic eddies are simulated: (1) CE-Jun1 $\left(81.5^{\circ} \mathrm{E}, 15^{\circ} \mathrm{N}\right)$; (2) CE-Jun2 $\left(82.5^{\circ} \mathrm{E}, 7.5^{\circ} \mathrm{N}\right)$ and $(3)$ CE-Jun3 $\left(97^{\circ} \mathrm{E}, 16^{\circ} \mathrm{N}\right)$. Two anticyclonic eddies, ACE-jun $1\left(81^{\circ} \mathrm{E}, 11^{\circ} \mathrm{N}\right)$ and ACE-Jun2 $\left(84^{\circ} \mathrm{E}, 17^{\circ} \mathrm{N}\right)$, are also observed in the simulation. These eddies are generally deep (500 - $1200 \mathrm{~m}$ ); see Table 4. The alternate cyclonic and anticyclonic circulation cells on the western boundary results in no well-defined coastal current during the June simulation (Figure 10(d)), and this is confirmed by observations [20] [21] [32]. Furthermore, a strong cyclonic gyre circulation is established at the head of the Bay, centered at $18^{\circ} \mathrm{N}$ (Figure 10(c)). Over time (from day 6 to day 15 of the integration), this gyre becomes stronger and double-cored (Figure 10(d)). The formation of this gyre during June is also reported by the study of [13]. A cyclonic gyre $\left(95^{\circ} \mathrm{E}, 14^{\circ} \mathrm{N}\right)$ circulation in the Andaman Sea is also established on day 15.

Westward and southwestward flows from the convergence zones between the cyclonic and anticyclonic eddies on the western boundary enter the mid BOB region and eventually merge with the western branch of the cyclonic gyre in the Andaman Sea. The simulation shows that the SMC flow enters the BOB between $80^{\circ}-90^{\circ} \mathrm{E}$ (Figure 10(d)). This has been reported from observations by [32] and by [33] and also from model studies by [13] [34] and [35]. During this season, a weak Malacca Strait flow from the BOB is simulated. A strong upwelling zone is observed near the southeastern coast of Sri Lanka in the simulation (Figure 10(d)); this feature has also been reported in an earlier study [36].

During October (Climo-1/4-Oct) when the northeast monsoon arrives, the surface circulation changes again, as shown in Figure 11. The development of a well-defined boundary current called the East India Coastal Current (EICC) is observed on day 6 of the simulation (Figure 11(a)). The basin-scale cyclonic gyre starts developing on day 9 (Figure 11(b)) and becomes fully developed by day 12 (Figure 11(c)). A number of mesoscale cyclonic and anticyclonic eddies (CE and AE) are observed on both sides of the basin and are fully developed by day 15 of the simulation (Figure 11(d)). Two AEs-ACE-Oct1 $\left(91^{\circ} \mathrm{E}, 21^{\circ} \mathrm{N}\right)$ and ACE-Oct2 $\left(93^{\circ} \mathrm{E}, 18^{\circ} \mathrm{N}\right)$-and five CEs-CE-Oct1 $\left(97^{\circ} \mathrm{E}, 16^{\circ} \mathrm{N}\right)$, CE-Oct2 $\left(95^{\circ} \mathrm{E}, 10^{\circ} \mathrm{N}\right), \operatorname{CE}-\operatorname{Oct} 3\left(83^{\circ} \mathrm{E}, 11^{\circ} \mathrm{N}\right)$, CE-Oct $4\left(83^{\circ} \mathrm{E}, 13^{\circ} \mathrm{N}\right)$ and CE-Oct5 $\left(91^{\circ} \mathrm{E}, 12.5^{\circ} \mathrm{N}\right)$ - are simulated. The two anticyclonic eddies along the Myanmar coast are deep (400 $500 \mathrm{~m}$ ), while the cyclonic eddies in the eastern basin are shallow $(40-70 \mathrm{~m})$. The cyclonic Yangon eddy at $97^{\circ} \mathrm{E}, 16^{\circ} \mathrm{N}$ near the Yangon coast is observed in all three months and is shallow in its vertical extent $(\sim 100 \mathrm{~m})$, possibly controlled by a topographic bank on its southwestern side. The CE-Oct3 and CE-Oct4 eddies are separated by a topographic bank and found to be restricted to the upper $150 \mathrm{~m}$. The warm water penetration to the Andaman Sea via the Malacca Strait is similar but weaker (Figure 11(d)) than in the February simulation (Figure 9(d)). The simulated surface flow from the Bay of Bengal to the Arabian Sea via the Palk Strait was observed and reported through geostrophic current computation by [20]-[22], and from ship-drift currents [27], direct current measurements [55] and model analysis [56]. Figure 11(d) shows the southward EICC bifurcating near the northern tip of Sri Lanka. One branch follows the eastern coast of Sri Lanka and turns eastward at $8^{\circ} \mathrm{N}$, forming the north equatorial current (NEC), and the other branch passes through the Palk Strait and again bifurcates, with one branch flowing to the Arabian Sea and another flowing south along the Sri Lankan coastline. This eastward flow forms the basin-scale cyclonic gyre setup. An anticyclonic eddy (AE) is seen at the head of the Bay in the simulation. The flow through the Malacca Strait merges into the eastern boundary current along the Malaysian coast (Figure 11(d)).

\subsubsection{Subsurface $(100 \mathrm{~m})$ Circulation}

The subsurface circulations in the three experiments are shown in Figure 12 on day 6 (left) and day 15 (right). In February (Climo-1/4-Feb), a large warm-core anticyclonic gyre $\left(85^{\circ} \mathrm{E}, 18^{\circ} \mathrm{N}\right)$ is evident at $100 \mathrm{~m}$, with a northward WBC in the western basin. A small warm-core anticyclonic eddy $\left(97^{\circ} \mathrm{E}, 8^{\circ} \mathrm{N}\right)$ and a cold-core cyclonic eddy $\mathrm{CE}\left(95^{\circ} \mathrm{E}, 12^{\circ} \mathrm{N}\right)$; neither of which have surface expression, are seen to develop by day 15 in the An- 
daman Sea. The Myanmar cyclonic gyre $\left(92^{\circ} \mathrm{E}, 18^{\circ} \mathrm{N}\right)$ has a signature down to $100 \mathrm{~m}$ and below. The western and eastern boundary currents are narrow and strong. Both boundary currents move northward toward the confluence region at the head of the Bay. The subsurface signature of the southwestward NEC is also evident in the simulation (Figure 12(b)) in the broad flow out of the BOB toward the Arabian Sea south of Sri Lanka. Similar flow patterns and eddies at the subsurface have also been reported in earlier studies [13] [19] [27].

In the June (Climo-1/4-Jun) simulation at $100 \mathrm{~m}$, subsurface counterparts of the surface cyclonic eddies at $81.5^{\circ} \mathrm{E}, 14.5^{\circ} \mathrm{N}$ and $82.5^{\circ} \mathrm{E}, 8^{\circ} \mathrm{N}$ are well simulated by day 15 . These are the subsurface expressions of the surface eddies and have been reported by [24] and [36] respectively. According to [38], the formation of the cyclonic eddy at $81.5^{\circ} \mathrm{E}, 14.5^{\circ} \mathrm{N}$ is primarily due to topography and baroclinic instability. [36] argued that the formation of the Sri Lanka Dome at $82.5^{\circ} \mathrm{E}, 8^{\circ} \mathrm{N}$ is due to wind-stress curl. The cyclonic gyre centered at $88^{\circ} \mathrm{E}$, $18^{\circ} \mathrm{N}$ is also evident at $100 \mathrm{~m}$. In addition, two cyclonic subsurface eddies at $93^{\circ} \mathrm{E}, 10^{\circ} \mathrm{N}$ and $87^{\circ} \mathrm{E}, 12^{\circ} \mathrm{N}$ are simulated by day 15 (Figure 12(d)). The SMC is observed at around $8^{\circ} \mathrm{N}$, where it joins with the Sumatra coastal current to form the eastern boundary current, which flows around the basin and ends up at the east coast of India around $14^{\circ} \mathrm{N}$. It is interesting to note that, rather than seeing surface eddies at the western boundary, a continuous southward-flowing EICC develops along the western boundary in this simulation.

During the month of October (Climo-1/4-Oct), the basin-scale cyclonic gyre that is seen at the surface (Figure 11(d)) intensifies to the west (Figure 12(e), Figure 12(f)), in agreement with observations by [57]. The cyclonic eddies on the western side of the basin $\left(86.5^{\circ} \mathrm{E}, 19^{\circ} \mathrm{N} ; 82.5^{\circ} \mathrm{E}, 14^{\circ} \mathrm{N} ; 79.5^{\circ} \mathrm{E}, 5^{\circ} \mathrm{N} ; 83^{\circ} \mathrm{E}, 10^{\circ} \mathrm{N}\right)$ and anticyclonic eddies on the eastern side of the basin $\left(97^{\circ} \mathrm{E}, 7^{\circ} \mathrm{N} ; 95^{\circ} \mathrm{E}, 12^{\circ} \mathrm{N} ; 91^{\circ} \mathrm{E}, 17^{\circ} \mathrm{N}\right)$ are observed to develop in a robust manner from day 6 (Figure 12(e)) to day 15 (Figure 12(f)). A strong EICC flow is seen to develop, encircling the coast of Sri Lanka by day 15 (Figure 12(f)). There is no flow either through the Palk Strait or through the Malacca Strait because of their shallowness. The simulation shows the penetration of flow from the Indian Ocean to the BOB between $80^{\circ} \mathrm{E}$ and $90^{\circ} \mathrm{E}$, which was also reported by [56]. The Andaman Sea is warmer and disorganized in nature on day 6 (Figure 12(e)) of the model simulation, but by day 15 (Figure 12(d)) two anti-cyclonic eddies at $95^{\circ} \mathrm{E}, 12^{\circ} \mathrm{N}$ and $97^{\circ} \mathrm{E}, 7^{\circ} \mathrm{N}$ have developed in the region. In contrast to February and June, the western side of the basin is now colder than the eastern side, which was also reported by [18].

\subsubsection{Deep (1500 m) Circulation}

Figure 13 shows the deep BOB circulation on day 6 (left) and day 15 (right) in each of the three months. At $1500 \mathrm{~m}$, the prevalent cyclonic gyre is evident during all months in the western basin. The formation of the cyclonic gyre in the western basin is possibly due to the dominant influences of coastal Kelvin waves travelling along the boundary of the basin [58]. This is probably due to topographic control and is disconnected from the wind-driven variability seen in the upper thermocline region. For example, during the month of February (Climo-1/4-Feb), the currents at $1500 \mathrm{~m}$ depth show a basin-scale CG from day 6 (Figure 13(a)), which becomes stabilized by day 15 (Figure 13(b)). An independent anticyclonic gyre in the Andaman Sea region, which is constrained by topography, develops during all three months. Note also that at this depth, the eastern basin is generally warmer than the western basin (Figure 13(d)).

\subsection{A Unique Salinity Signature in the Northern Bay during February}

The surface salinity in the BOB region is low compared to other parts of the world's oceans and is quite well-simulated by the model (Figures 14(a)-14(f)). A low-salinity signature in the coastal region is also reproduced reasonably well by the model simulations.

The advection of high salinity along the eastern coast of India by the northward-propagating WBC during February (Climo-1/4-Feb) is seen from day 6 of the model simulation (Figure 14(a)). Interestingly, it forms a hammerhead-like structure at the head of the BOB by day 15 of the model simulation at around $88^{\circ} \mathrm{E}, 21^{\circ} \mathrm{N}$ (Figure 14(b)), where the WBC develops into a pair of mesoscale eddies bracketing the main flow (Figure 9(d)). A similar signature visible from the Moderate Resolution Imaging Spectroradiometer (MODIS) chlorophyll data composited over a one-week period (February 8-14, 2008) is presented in Figure 15. This sub-mesoscale structure is probably realized as a result of the contrast between the high-salinity content in the paired vortices formed off of the WBC and the adjacent fresh waters from the river-delta region in the North Bay.

During the month of June (Climo-1/4-Jun), the head of the BOB (near $20^{\circ} \mathrm{N}$ ) shows low salinity. This lowsalinity tongue is advected southward along the coast of India on day 6 (Figure 14(c)); its extent can be seen up 

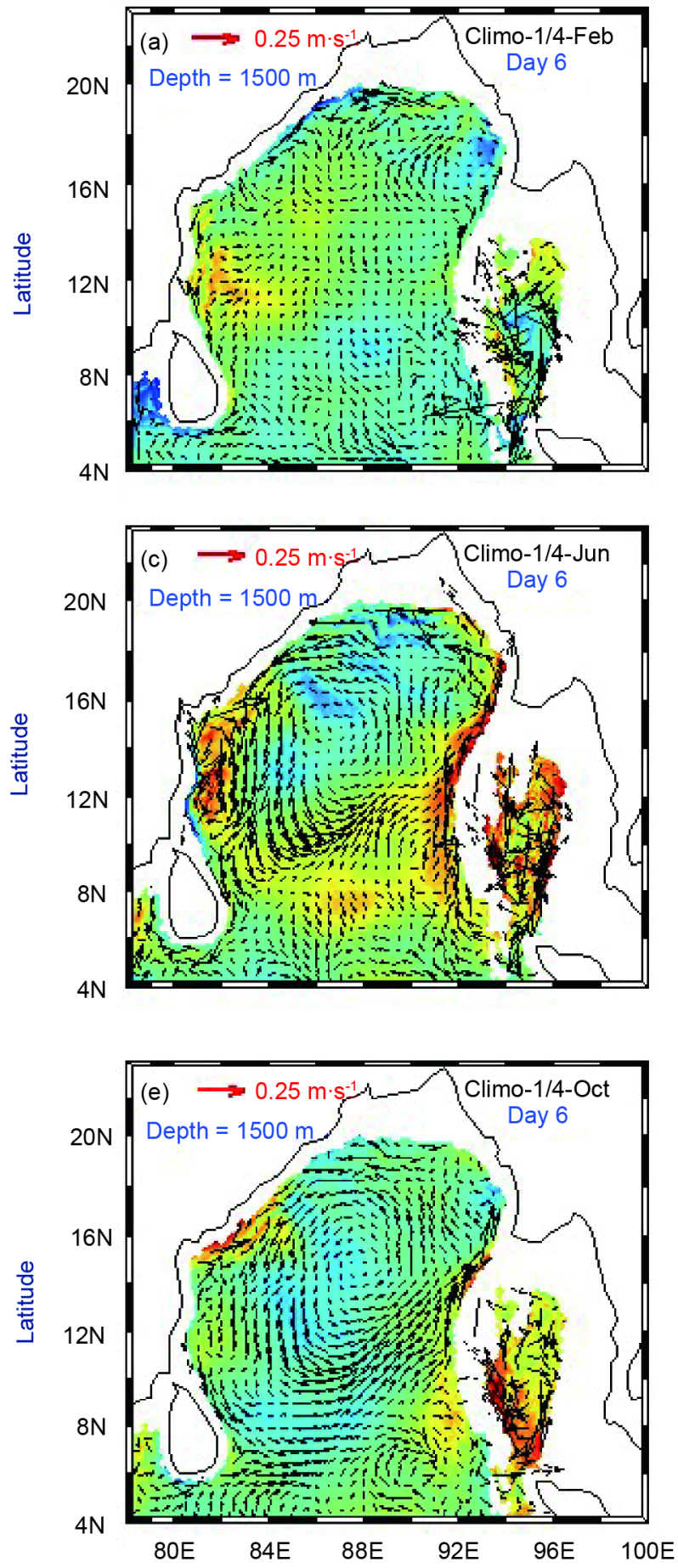

Longitude
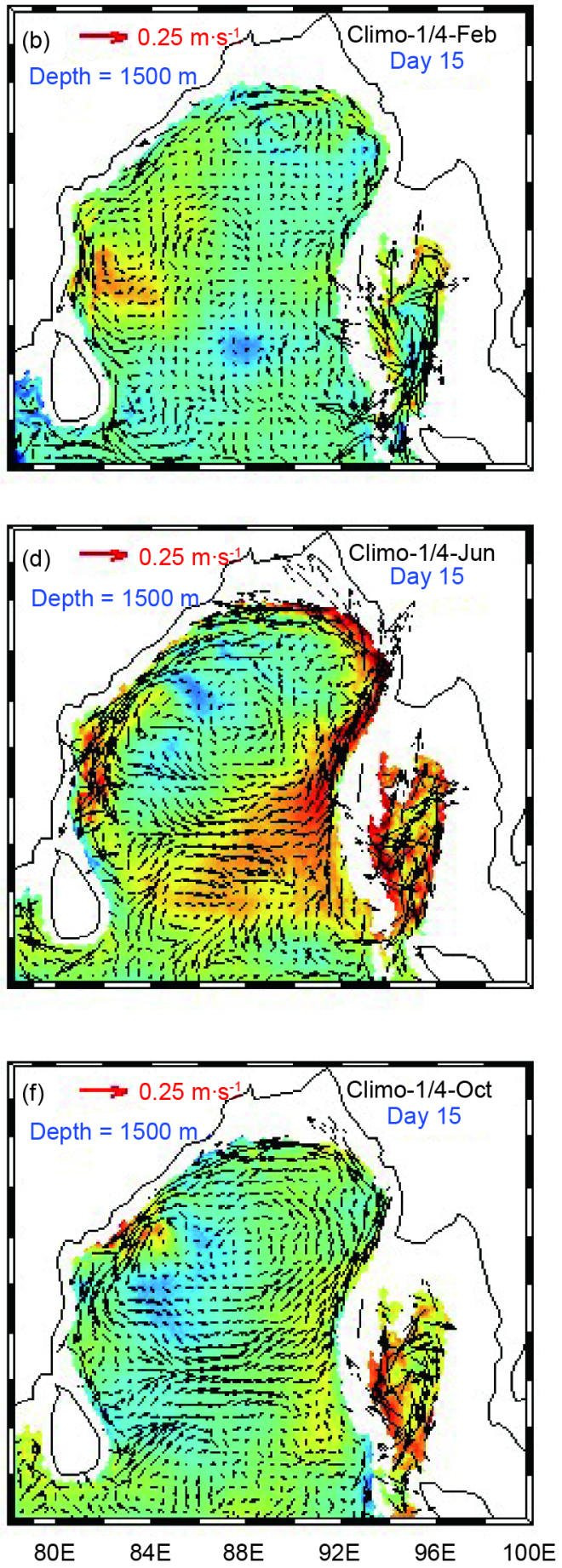

Longitude

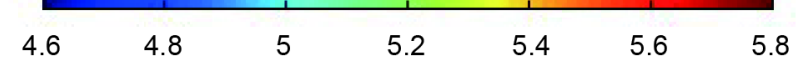

Figure 13. Model-simulated currents (vectors) with temperature (colored) at $1500 \mathrm{~m}$ depth for: (a) day 6 of the Climo-1/4-Feb experiment; (b) day 15 of the Climo-1/4-Feb experiment; (c) day 6 of the Climo-1/4-Jun experiment, (d) day 15 of the Climo-1/4-Jun experiment; (e) day 6 of the Climo-1/4-Oct experiment; and (f) day 15 of the Climo-1/4-Jun experiment. 

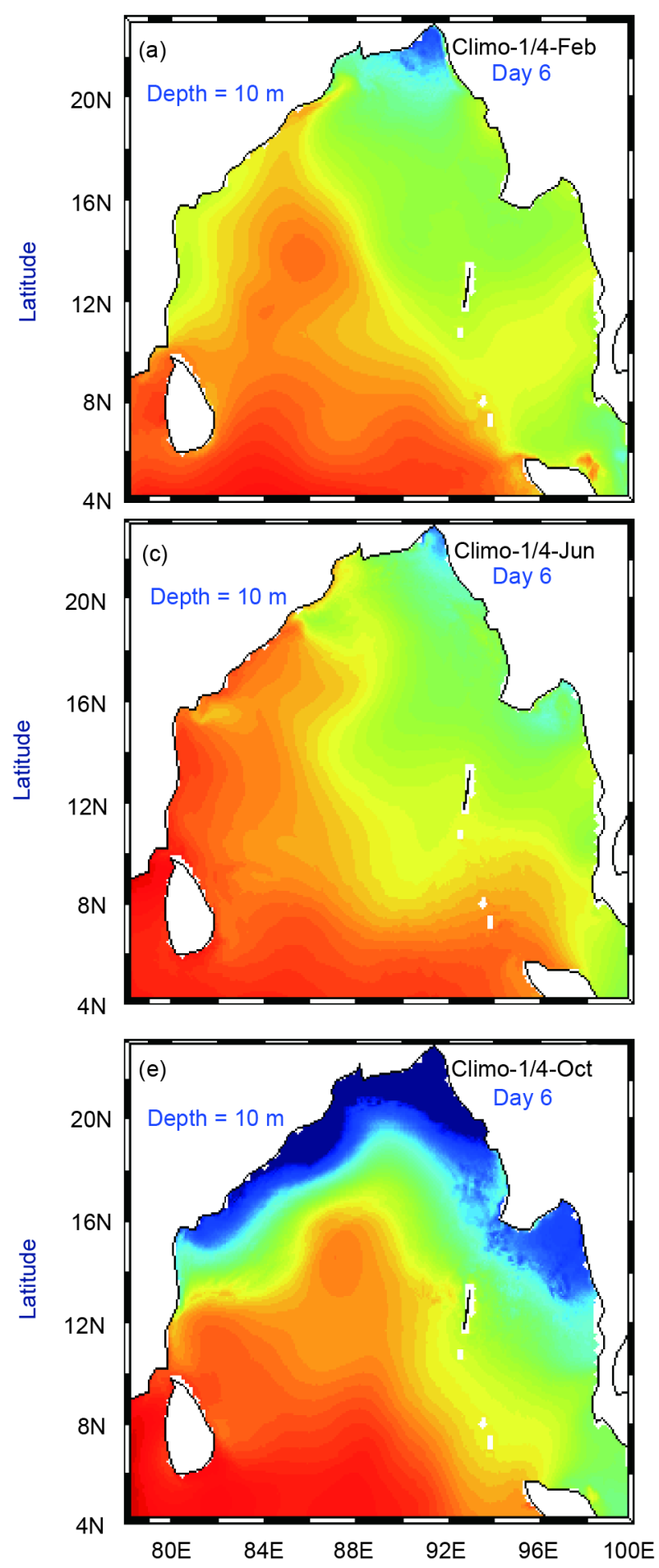

Longitude
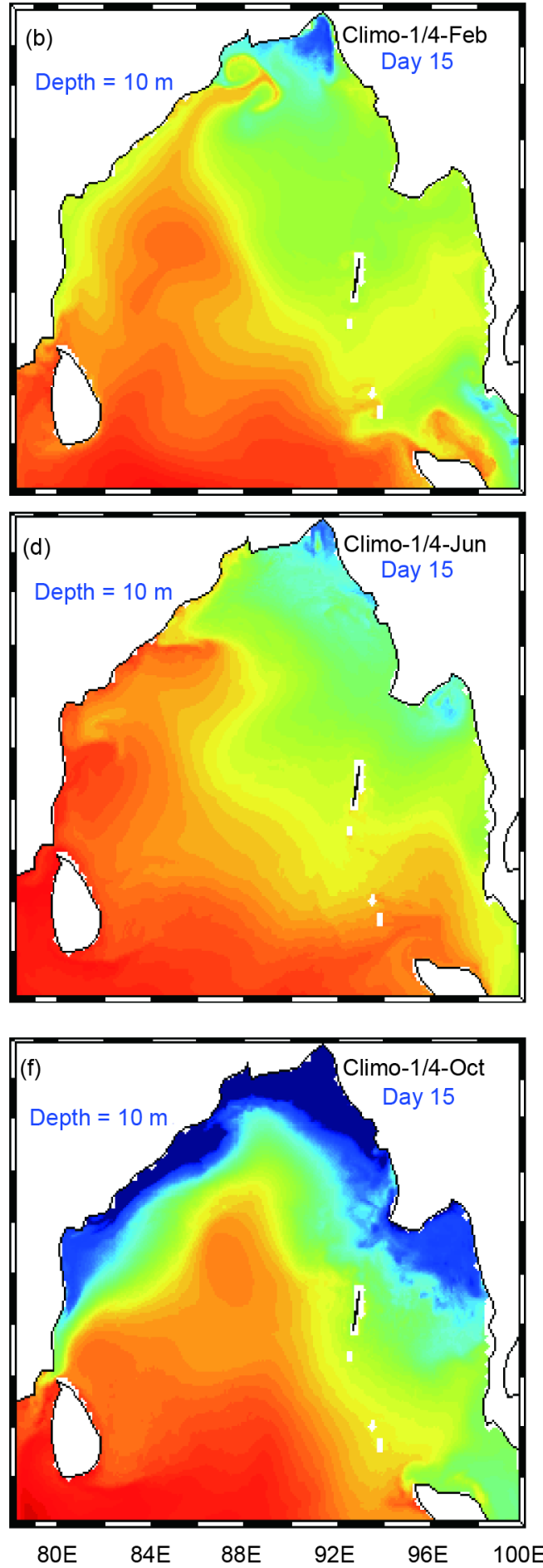

Longitude

28

30

32

34

36

Figure 14. Model-simulated salinity (colored) at $10 \mathrm{~m}$ depth for: (a) day 6 of the Climo-1/4-Feb experiment; (b) day 15 of the Climo-1/4-Feb experiment; (c) day 6 of the Climo-1/4-Jun experiment; (d) day 15 of the Climo-1/4-Jun experiment; (e) day 6 of the Climo-1/4-Oct experiment; and (f) day 15 of the Climo-1/4-Jun experiment. 


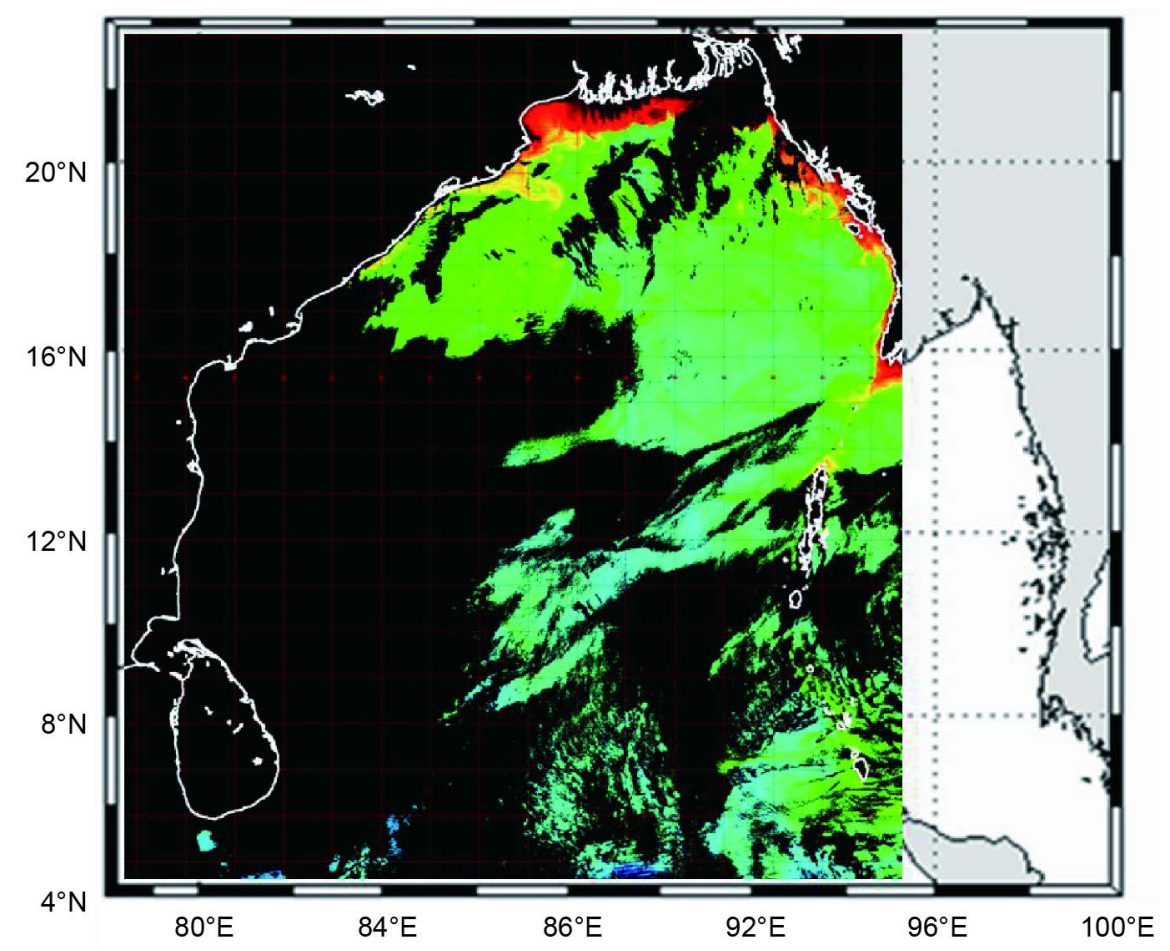

Figure 15. MODIS chlorophyll data (one-week composite) over the Bay of Bengal region for February 8-14, 2008. The hammerhead structure is visible in the North Bay region.

to $19^{\circ} \mathrm{N}$ by day 15 (Figure $14(\mathrm{~d})$ ). High-salinity water penetration from the Arabian Sea and Indian Ocean into the lower part of the BOB is seen in the model simulation (Figure 14(d)) and is due to the time-dependent boundary conditions. This penetration was also observed in a study by [56].

The head of the Bay and the east coast of India show the lowest salinity (Figure 14(e), Figure 14(f)) during the October simulation (Climo-1/4-Oct), when the southwesterly wind weakens and the atmospheric surface flow starts changing direction. The low-salinity area increases in size from day 6 (Figure 14(e)) to day 15 (Figure 14(f)) of the model simulation. Both the eastern and western boundaries of the basin above $12^{\circ} \mathrm{N}$ show minimal salinity. This is due to the boundary currents (WBC and Myanmar coastal current) carrying low-salinity water from the head of the Bay southward (Figure 14(d)).

\subsection{Comparison of Simulations with Drifter and ARGO Climatologies}

The surface circulations from the three monthly simulations are presented schematically in Figure 16(a), Figure 16(b) and Figure 16(c) for February, June and October, respectively. The simulated basin-scale gyre-like features can be compared with available drifter climatology for this region, presented in Figure 17(a), Figure 17(b) and Figure 17(c). The drifter climatology is based on monthly average of all available drifter data from 1973 through 2009 (http://www.aoml.noaa.gov/phod/dac/drifter_climatology.html). The quality control, interpolation methods for deriving the drifter climatology and example validations for Atlantic and Pacific oceans are provided by [59]-[62].

The simulated anticyclonic gyre in the western basin in February (Figure 16(a)) transitions to a series of ACEs and CEs with a cyclonic gyre developing in the north Bay by June (Figure 16(b)), which agree well with drifter climatology circulations in Figure 17(a) and Figure 17(b). The drifter-derived currents at 1-degree resolution show clear separation of the western boundary current from the coast with rather disorganized flow upstream, which could be the signature of eddies evident in the mesoscale-resolving simulation fields in Figure 16(b) The simulated basin-wide cyclonic gyre during October (Figure 16(c)) is also evident in the drifter climatology (Figure 17(c)). Note that there was a lack of drifter observations in the Andaman Sea and through Malacca Straits, which renders the drifter climatology to show steady outflow during all the three months; however, our simulations indicate inflow during February and October, which agree with the observations of [27]. 


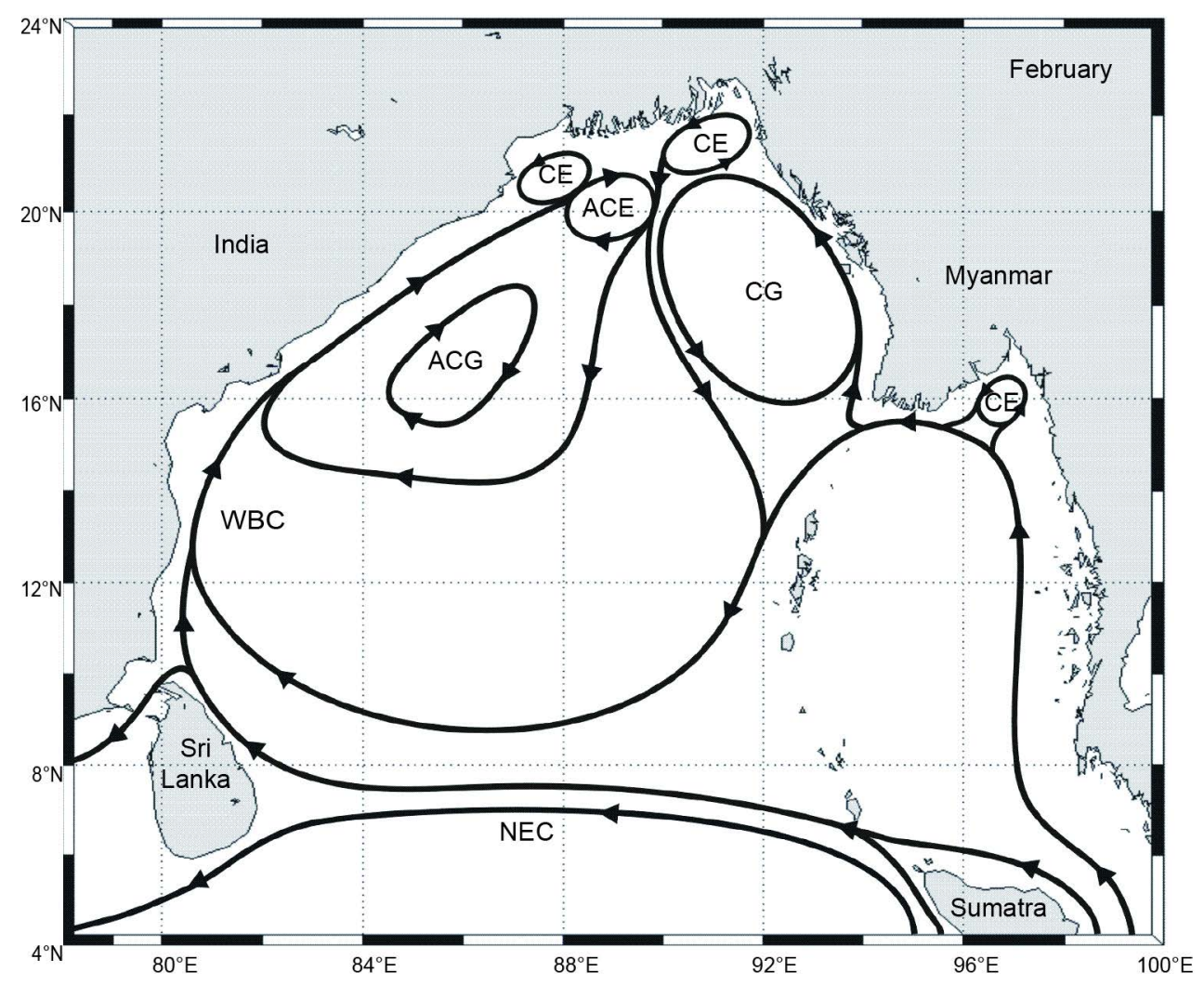

(a)

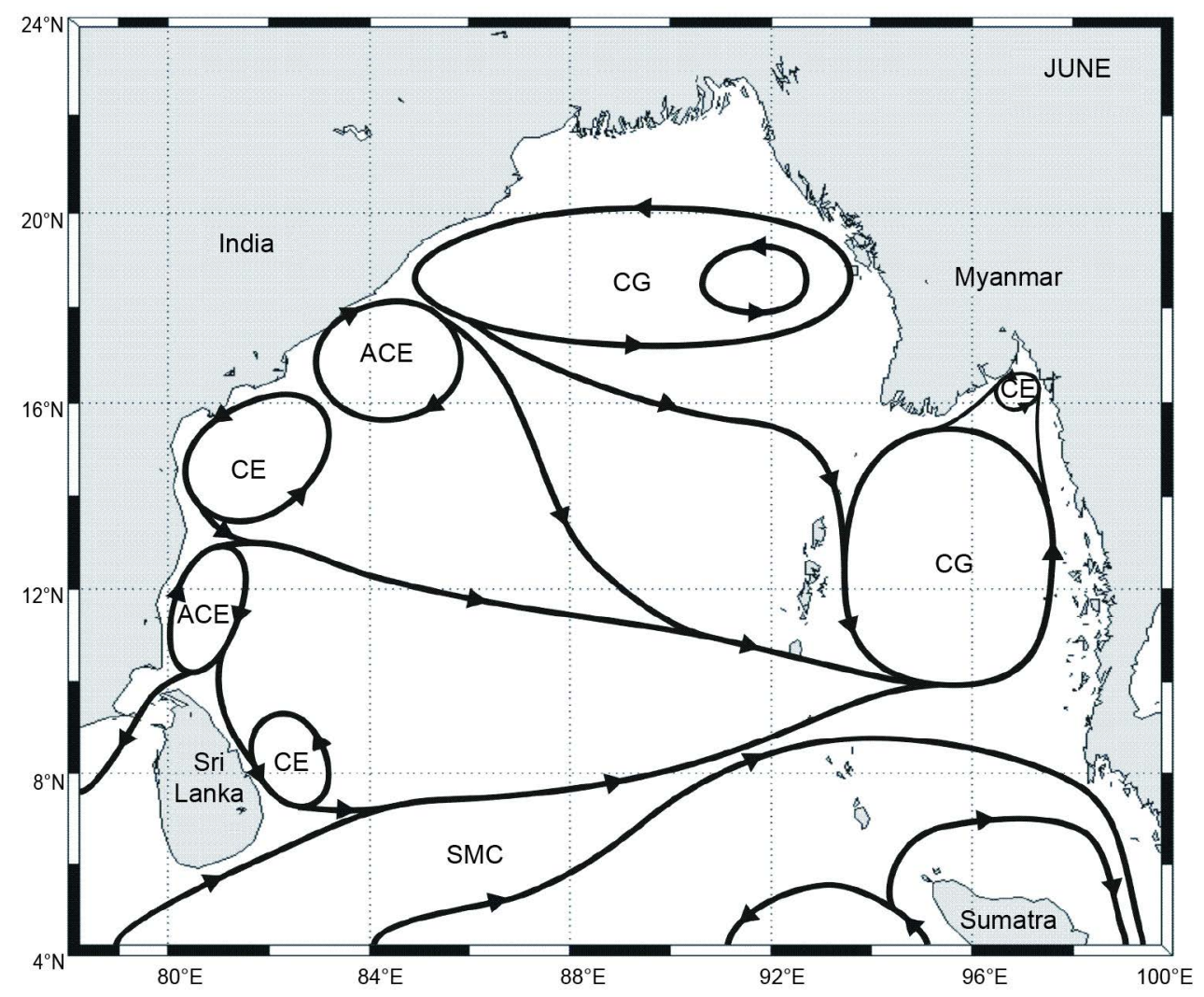

(b) 


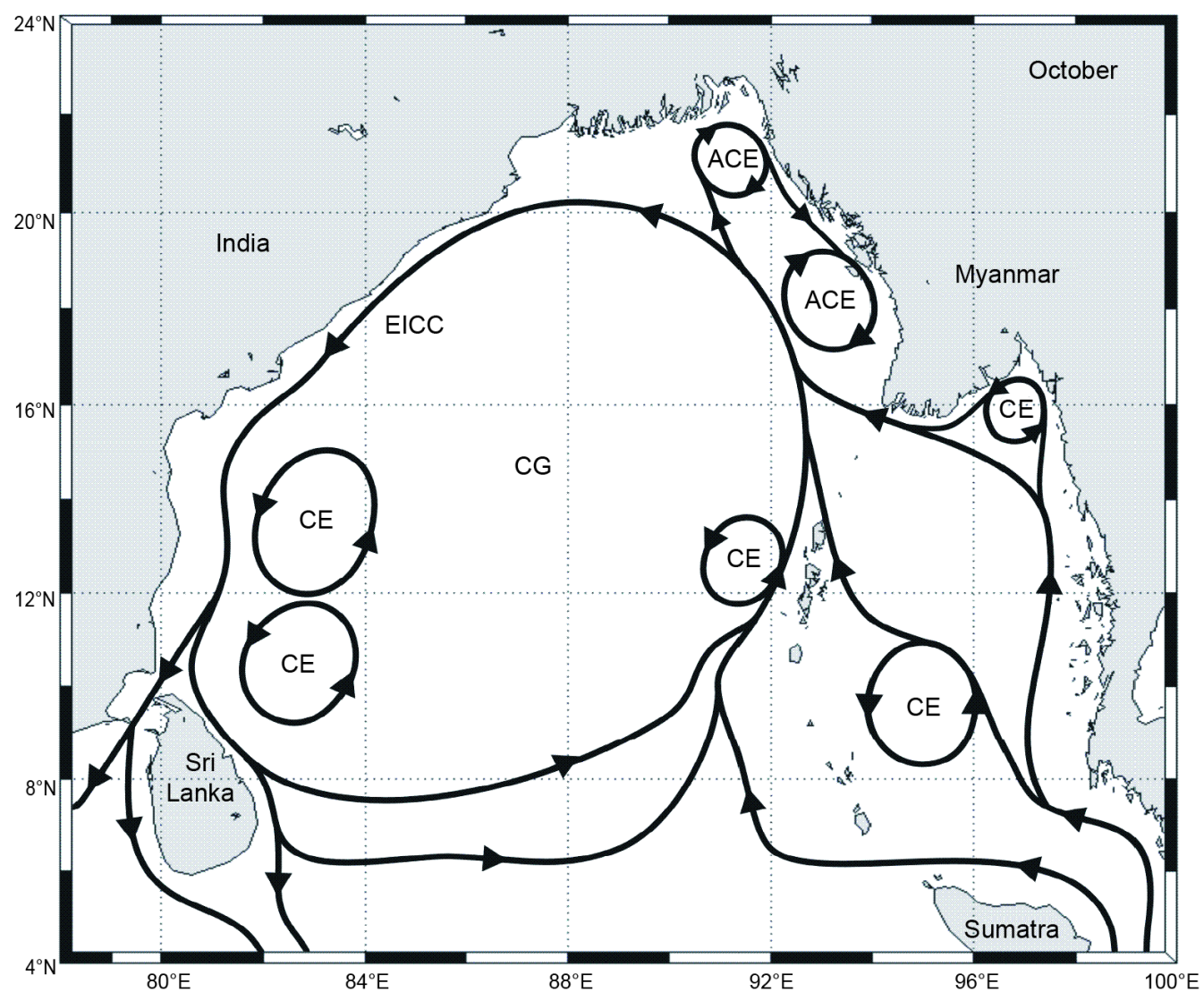

(d)

Figure 16. Schematic of the multiscale synthesis of surface circulation consisting of currents, eddies and gyres as simulated by the high-resolution model for: (a) February, (b) June and (c) October. See text for details.
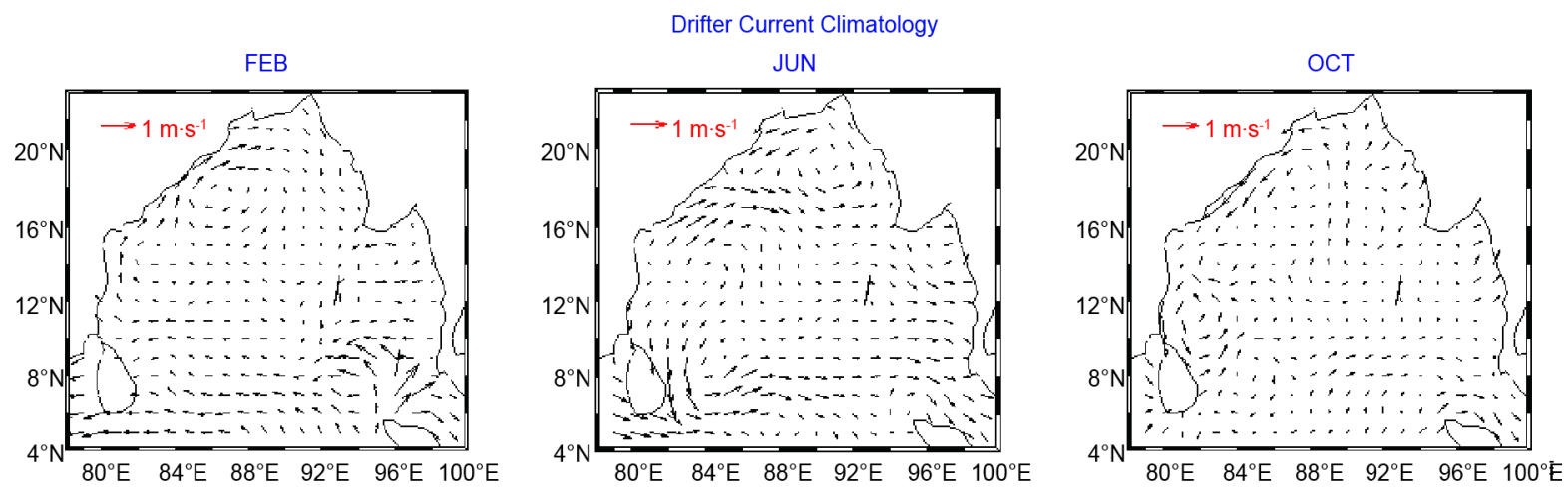

Figure 17. Drifter-based climatology of surface currents for: (a) February, (b) June and (c) October. Compare these figures with the synoptic synthesis schematics in Figure 16.

Furthermore, the simulated temperature profiles are compared with available ARGO mean profiles at selected locations for the three months. Three locations for each month were chosen within a particular feature (an eddy or a gyre) developed during the simulation. The mean profiles from ARGO data were determined from the mean of observations within a $0.5^{\circ} \times 0.5^{\circ}$ box centered on the selected location. Each mean profile was computed from at least five ARGO profiles available in the box between 2003 and 2009. The chosen locations for the comparison in February (Figure 18) are the Myanmar CG in the eastern basin, the ACG in the western basin and the ACE in the North Bay. The North Bay cyclonic gyre, the small cyclonic eddy to the east of Sri Lanka and the 
ACE off of Southern India near $11^{\circ} \mathrm{N}$ was chosen for the June simulation comparison (Figure 19). Three cyclonic eddies - two in the western basin and one west of the Andaman Island were chosen for the October simulation (Figure 20). In all of these comparisons (Figures 18-20), the simulated temperature profiles seem to follow the observed (ARGO) mixed layer depths and thermocline slopes reasonably well.

\section{Summary and Conclusions}

A high-resolution ocean prediction system has been developed for the BOB region using ROMS. Different multiscale features simulated by this high-resolution modeling system initialized with climatology data for three particular months (February, June and October) are discussed in this paper. Note that similar climatology-based simulations for the other none months will be described in a later paper. This model has been able to resolve most of the known circulation features of the Bay of Bengal in reasonable agreement with earlier analyses [13] [14] [18] [36] [56] [62] [63] and observations [19] [27] [64]. Some new features were also observed in the model simulations. Table 4 provides a list of the simulated eddies and gyres, along with available observational evidence. Unfortunately, observational synoptic section data for the Bay are rare; thus, we restricted our physical validation to these eddies and the frontal transport values at particular sections (see Table 5) where minimal data and published results are available. This lack of data suggests a need for coordinated efforts to survey and collect data across the Bay on a regular basis in the future.
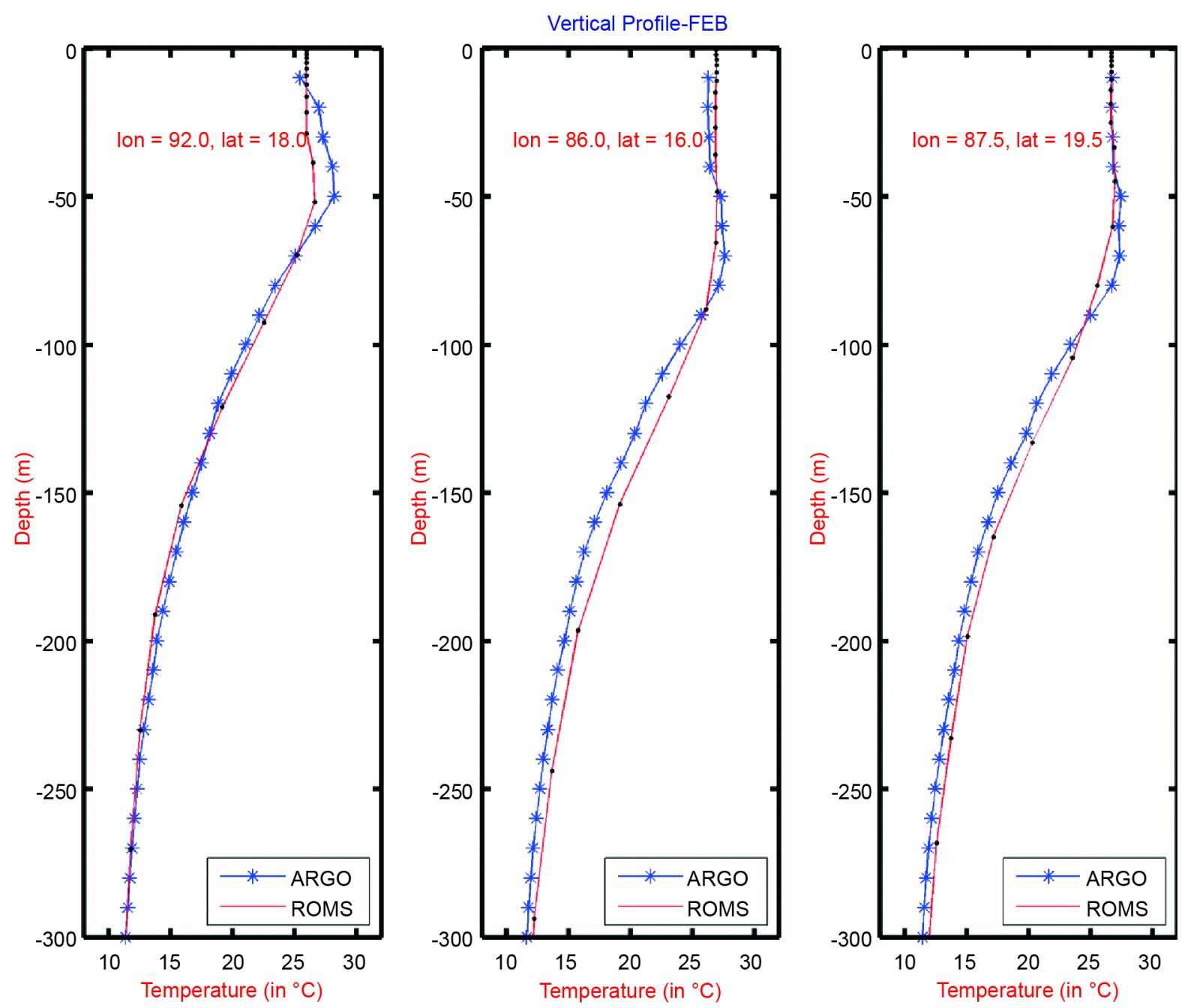

Figure 18. Comparison of simulated temperature profile with mean ARGO profile during February at selected locations: (a) CG $\left(92^{\circ} \mathrm{E}, 18^{\circ} \mathrm{N}\right),\left(\right.$ b) ACG $\left(86^{\circ} \mathrm{E}, 16^{\circ} \mathrm{N}\right)$ and (c) ACE_feb1 $\left(87.5^{\circ} \mathrm{E}, 19.5^{\circ} \mathrm{N}\right)$. 

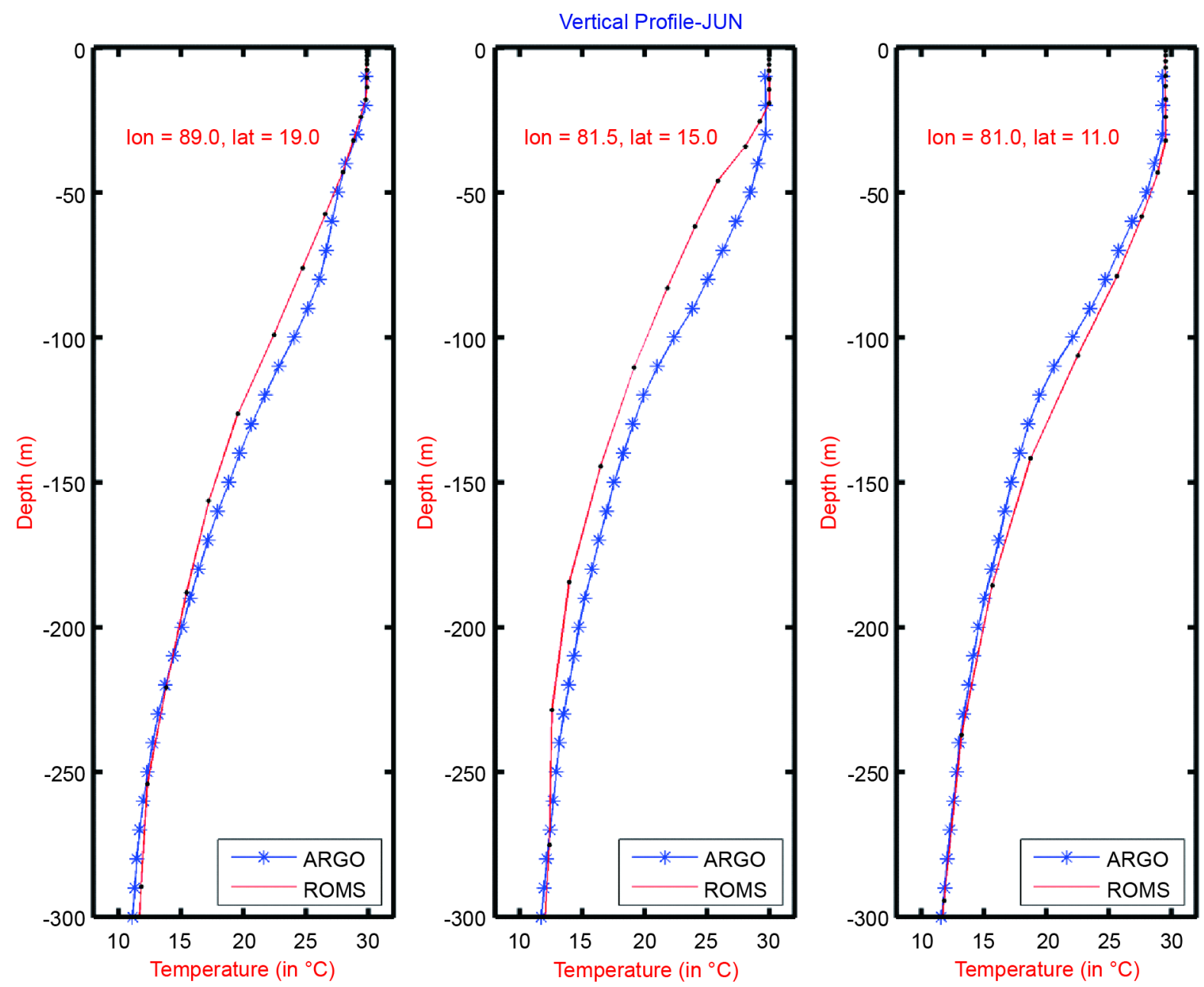

Figure 19. Comparison of simulated temperature profile with mean ARGO profile during June at selected locations: (a) CG $\left(89^{\circ} \mathrm{E}, 19^{\circ} \mathrm{N}\right)$, (b) CE jun $1\left(81.5^{\circ} \mathrm{E}, 15^{\circ} \mathrm{N}\right)$ and (c) ACE jun $1\left(81^{\circ} \mathrm{E}, 11^{\circ} \mathrm{N}\right)$.

Based on the analysis of results presented in section 4, a synthesis of multiscale circulation elements is presented for each month in Figure 16(a), Figure 16(b) and Figure 16(c) for February, June, and October, respectively. Basin-scale and subbasin-scale gyres, mesoscale eddies, strait-scale inflows and outflows, strong boundary currents and broad-scale equatorial currents are the multiscale features simulated in the experiments. A basin-scale anticyclonic gyre with a strong WBC in the western basin and a cyclonic subbasin-scale Myanmar gyre are observed in the February simulation. These gyres show their signature in the subsurface ( $\sim 500 \mathrm{~m})$ region as well. Three cyclonic eddies and one anticyclonic eddy developed at the surface, while one cyclonic and one anticyclonic eddy developed at the subsurface. The advection of salt by the WBC during February and the formation of a shallow hammerhead high-salinity structure were simulated for the first time and were supported by satellite chlorophyll observations. During the June simulation, disorganized circulation was dominated by eddies along the western boundary. A deep ( $\sim 500 \mathrm{~m}$ ) cyclonic Andaman gyre was observed in the eastern basin. However, at the same time, a continuous southward EICC was simulated at $100 \mathrm{~m}$. The northern Bay cyclonic gyre shows its signature both at the surface and at depths up to $600 \mathrm{~m}$. Three cyclonic and two anticyclonic eddies developed at the surface, while four cyclonic eddies developed at $100 \mathrm{~m}$. Two of these cyclonic eddies had corresponding subsurface expression. In the October simulation, a basin-scale cyclonic gyre with strong EICC is seen both at the surface and at the subsurface. In addition, five cyclonic and two anticyclonic eddies developed at the surface, while four cyclonic and three anticyclonic eddies developed at $100 \mathrm{~m}$. It is interesting to note that the shallow cyclonic Yangon eddy exists in all three months. In the deeper layer $(1500 \mathrm{~m})$, the water mass characteristics of the two basins are different (Figures 2(a)-2(d)); the basin topography and possibly coastal Kelvin waves constrain 

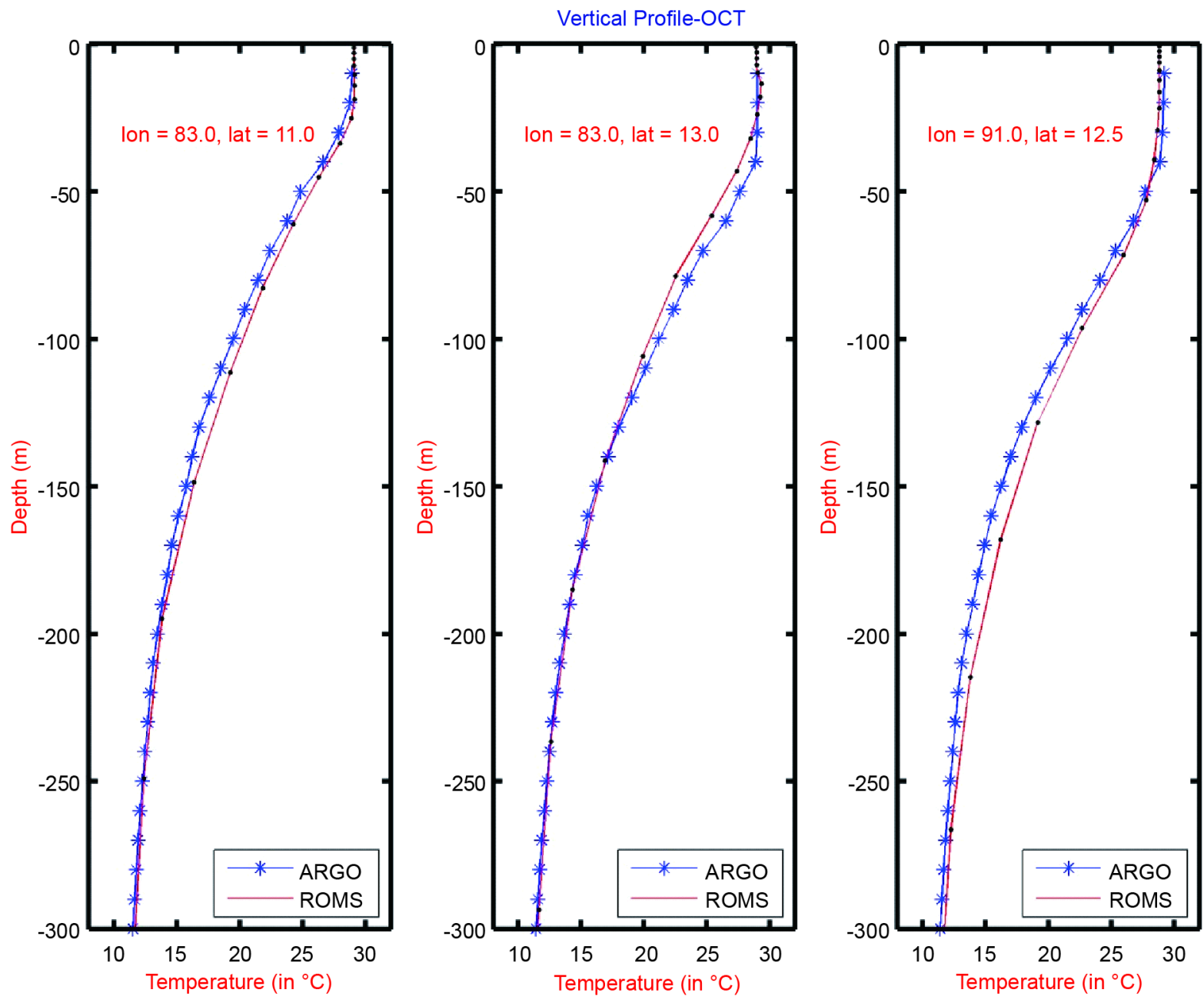

Figure 20. Comparison of simulated temperature profile with mean ARGO profile during October at selected locations: (a) CE_oct3 $\left(83^{\circ} \mathrm{E}, 11^{\circ} \mathrm{N}\right),\left(\right.$ b) CE_oct4 $\left(83^{\circ} \mathrm{E}, 13^{\circ} \mathrm{N}\right)$ and (c) CE_oct5 $\left(91^{\circ} \mathrm{E}, 12.5^{\circ} \mathrm{N}\right)$.

Table 5. Transport comparison between model and observations, where available. Model values are for day 15 of the simulations.

\begin{tabular}{cccccccc}
\hline & \multicolumn{5}{c}{ Transport values (Sv) } \\
\cline { 2 - 7 } Sections & \multicolumn{2}{c}{ February } & \multicolumn{3}{c}{ June } & October \\
\cline { 2 - 7 } & Model & Observations & Model & Observations & Model & Observations \\
\hline $88^{\circ} \mathrm{E}-92^{\circ} \mathrm{E}, 12^{\circ} \mathrm{N}$ & -2.15 & - & 1.05 & - & 5.34 & $6 \mathrm{~Sv}[32]$ \\
Palk Strait, $9^{\circ} \mathrm{N}$ & -0.49 & - & -0.03 & - & -0.67 & - \\
Malacca Strait $98^{\circ} \mathrm{E}, 5^{\circ} \mathrm{N}$ to $100^{\circ} \mathrm{E}, 7^{\circ} \mathrm{N}$ & 2.67 & - & -3.07 & - & 2.01 & - \\
$80^{\circ} \mathrm{E}-95^{\circ} \mathrm{E}, 6^{\circ} \mathrm{N}$ & -12.32 & - & 19.36 & $17 \mathrm{~Sv}[23]$ & -14.58 & $-16 \mathrm{~Sv}[29]$ \\
$80^{\circ} \mathrm{E}-84^{\circ} \mathrm{E}, 12^{\circ} \mathrm{N}$ & 18.27 & $16 \mathrm{~Sv}[31]$ & 22.04 & - & -27.72 & - \\
\hline
\end{tabular}

the circulation in two separate gyres - a cyclonic one in the west and an anticyclonic one to the east, independent of the season, as seen in these simulations. The outflow through the Palk Strait is weaker in June than in the other months. The Malacca Strait throughflow is toward the Andaman Sea in February and October and reverses in June. 
Simulation comparisons with drifter climatology for basin-scale feature and with ARGO profiles for mesoscale features also show reasonable agreement. Thus, these climatology-based monthly simulations can now provide the basis for ocean state forecasting for this region, and an October 2008 application with Tropical Rain Measuring Mission (TRMM) satellite's microwave imager (TMI) and ARGO data assimilation will be reported in part II of this series of papers.

\section{Acknowledgments}

The authors also gratefully acknowledge the financial support given by the Earth System Science Organization (ESSO) - Indian National Centre for Ocean Information Services (INCOIS), Ministry of Earth Sciences, and Government of India to conduct this research. We are thankful to Dr. Andre Schmidt, Dr. Ayan H. Chaudhuri and Ms. Carolina Nobre for their help with model setup, analysis and graphics preparation. Special thanks to the members of the OMAL during Professor Chakraborty's visit. We thank Mr. Frank Smith for his editorial assistance.

\section{References}

[1] Griffiths, C.R. (2002) Indian Ocean Global Ocean Observing System. First Conference of the Indian Ocean Global Ocean Observing System, Mauritius, 2-9 November 2002, Report Number: IOGOOS CR 2002 (1).

[2] Ezer, T. and Mellor, G.L. (1997) Data Assimilation Experiments in the Gulf Stream Region: How Useful Are Satellite-Derived Surface Data for Nowcasting the Subsurface Fields? Journal of Atmospheric and Oceanic Technology, 16, 1379-391. http://dx.doi.org/10.1175/1520-0426(1997)014<1379:DAEITG>2.0.CO;2

[3] Holland, W.R., and Malanotte-Rizzoli, P. (1989) Assimilation of Altimeter Data into an Ocean Circulation Model: Space versus Time Resolution Studies. Journal of Physical Oceanography, 19, 1507-1534. http://dx.doi.org/10.1175/1520-0485(1989)019<1507:aoadia>2.0.co;2

[4] Auroux, D. and Blum, J. (2008) A Nudging-Based Data Assimilation Method for Oceanographic Problems: The Back and Forth Nudging (BFN) Algorithm. Nonlinear Processes in Geophysics, 15, 305-319. http://dx.doi.org/10.5194/npg-15-305-2008

[5] Lozano, C.J., Robinson, A.R., Arango, H.G., Gangopadhyay, A., Sloan, N.Q., Haley, P.J. and Leslie, W.G. (1996) An Interdisciplinary Ocean Prediction System: Assimilation Strategies and Structured Data Models. In: Malanotte-Rizzoli, P., Ed., Modern Approaches to Data Assimilation in Ocean Modelling, Elsevier Oceanography Series, Elsevier, The Netherlands, 413-452. http://dx.doi.org/10.1016/S0422-9894(96)80018-3

[6] Daley, R. (1991) Atmospheric Data Analysis. Cambridge Atmospheric and Space Science Series, Cambridge University Press, $457 \mathrm{p}$.

[7] Courtier, P., Anderson, E., Heckley, W., Pailleux, J., Vasiljevic, D., Hamrud, M., Hollingsworth, A., Rabier, F. and Fisher, M. (1998) The ECMWF Implementation of Three-Dimensional Variational Assimilation (3D-Var). Part 1: Formulation. Quarterly Journal of the Royal Meteorological Society, 124, 1783-1807.

[8] Courtier, P., Thépaut, J.-N. and Hollingsworth, A. (1994) A Strategy for Operational Implementation of 4D-VAR, Using an Incremental Approach. Quarterly Journal of the Royal Meteorological Society, 120, 1367-1387. http://dx.doi.org/10.1002/qj.49712051912

[9] Courtier, P. (1997) Dual Formulation of Four-Dimensional Variational Assimilation. Quarterly Journal of the Royal Meteorological Society, 123, 2449-2461. http://dx.doi.org/10.1002/qj.49712354414

[10] Glenn, S.M. and Robinson, A.R. (1995) Validation of an Operational Gulf Stream Forecasting Model. In: Lynch, D.R. and Davies A.M., Eds., Qualitative Skill Assessment for Coastal Models, Vol. 47, AGU Estuarine/Coastal Series, American Geophysical Union, 469-499.

[11] Fox, D.N., Carnes, M.R. and Mitchell, J.L. (1992) Characterizing Major Frontal Systems: A Nowcast/Forecast System for Northwest Atlantic. Oceanography, 5, 49-53. http://dx.doi.org/10.5670/oceanog.1992.32

[12] Gangopadhyay, A., and Robinson, A.R. (2002) Feature Oriented Regional Modeling of Oceanic Fronts. Dynamics of Atmospheres and Oceans, 36, 201-232. http://dx.doi.org/10.1016/S0377-0265(02)00032-5

[13] Potemra, J.T., Luther, M.E. and O’Brien, J. (1991) The Seasonal Circulation of the Upper Ocean in the Bay of Bengal. Journal of Geophysical Research, 96, 12667-12683. http://dx.doi.org/10.1029/91jc01045

[14] McCreary, J.P., Kundu, P.K. and Molinari, R.L. (1993) A Numerical Investigation of Dynamics, Thermodynamics and Mixed-Layer Processes in the Indian Ocean. Progress in Oceanography, 31, 181-244. http://dx.doi.org/10.1016/0079-6611(93)90002-U

[15] McCreary, J.P., Han, W., Shankar, D. and Shetye, S.R. (1996) Dynamics of the East India Coastal Current: 2. Numeri- 
cal Solutions. Journal of Geophysical Research, 101, 13993-14000. http://dx.doi.org/10.1029/96JC00560

[16] Vinayachandran, P.N., Shetye, S.R., Sengupta, D. and Gadgil, S. (1996) Forcing Mechanisms of the Bay-of-Bengal Circulation. Current Science, 71, 753-763.

[17] Schott, F. and McCreary, J.P. (2001) The Monsoon Circulation of the Indian Ocean. Progress in Oceanography, 51, 1-123. http://dx.doi.org/10.1016/S0079-6611(01)00083-0

[18] Paul, S., Chakraborty, A., Pandey, P.C., Basu, S., Satsangi, S.K. and Ravichandran, M. (2009) Numerical Simulation of Bay of Bengal Circulation Features from Ocean General Circulation Model. Marine Geodesy, 32, 1-18. http://dx.doi.org/10.1080/01490410802661930

[19] Legeckis, R. (1987) Satellite Observations of a Western Boundary Current in the Bay of Bengal. Journal of Geophysical Research, 92, 12974-12978.

[20] Shetye, S.R., Gouveia, A.D., Shenoi, S.S.C., Sundar, D., Michael, G.S., Almeida, A.A. and Santanam, K. (1991a) The Coastal Currents off Western India during Northeast Monsoon. Deep Sea Research: Part A, 38, 1517-1529. http://dx.doi.org/10.1016/0198-0149(91)90087-V

[21] Shetye, S.R., Shenoi, S.S.C., Gouveia, A.D., Michael, G.S., Sundar, D. and Nampoothiri, G. (1991) Wind Driven Coastal Upwelling along the Western Boundary of the Bay of Bengal. Continental Shelf Research, 11, 1397-1408. http://dx.doi.org/10.1016/0278-4343(91)90042-5

[22] Shetye, S.R., Gouveia, A.D., Shenoi, S.S.C., Shankar, D., Vinayachandran, P.N., Sundar, D., Michael, G.S. and Nampothiri, G. (1996) Hydrography and Circulation and Circulation in the Western Bay of Bengal during the Northeast Monsoon. Journal of Geophysical Research, 101, 14011-14025. http://dx.doi.org/10.1029/95JC03307

[23] Varkey, M.J., Vaithiyanathan, R. and Santanam, K. (1996) Wind Fields of Storms from Surface Isobars for Wave Hindcasting. International Conference in Ocean Engineering, IIT Madras, India, 17-20 December 1996, 502-506.

[24] Babu, M.T., Sarma, Y.V.B., Murty, V.S.N. and Vethamony, P. (2003) On the Circulation in the Bay of Bengal during Northern Spring Inter-Monsoon (March-April 1987). Deep-Sea Research II, 50, 855-865. http://dx.doi.org/10.1016/S0967-0645(02)00609-4

[25] Somayajulu, Y.K., Murty, V.S.N. and Sarma, Y.V.B. (2003) Seasonal and Inter-Annual Variability of Surface Circulation in the Bay of Bengal from TOPEX/Poseidon Altimetry. Deep Sea Research II, 50, 867-880. http://dx.doi.org/10.1016/S0967-0645(02)00610-0

[26] Narvekar, J. and Kumar, S.P. (2006) Seasonal Variability of the Mixed Layer in the Central Bay of Bengal and Associated Changes in Nutrients and Chlorophyll. Deep-Sea Research I, 53, 820-835. http://dx.doi.org/10.1016/j.dsr.2006.01.012

[27] Cutler, A.N. and Swallow, J.C. (1984) Surface Currents of the Indian Ocean (to $25^{\circ} \mathrm{S}$ to $100^{\circ}$ E). Report No. 87 . Institute of Oceanographic Sciences, Broadchill, UK.

[28] Varadachari, V., Murty, C.S. and Das, P.K. (1968) On the Level of Least Motion and the Circulation in the Upper Layers of the Bay of Bengal. Bulletin of National Institute of Oceanography, 38, 301-307.

[29] Murty, V.S.N., Suryanarayana, A. and Rao, D.P. (1993) Current Structure and Volume Transport Across $12^{\circ}$ N in the Bay of Bengal. Indian Journal of Marine Sciences, 22, 12-16.

[30] Shetye, S.R., Gouveia, A.D., Shenoi, S.S.C., Sundar, D., Michael, G.S. and Nampothiri, G. (1993) The Western Boundary Current of the Seasonal Subtropical Gyre in the Bay of Bengal. Journal of Geophysical Research, 98, 945-954. http://dx.doi.org/10.1029/92JC02070

[31] Sanilkumar, K.V., Kuruvilla, T.V., Jogendranath, D. and Rao, R.R. (1997) Observations of the Western Boundary Current of the Bay of Bengal from a Hydrographic Survey during March 1993. Deep Sea Research I, 44, 135-145. http://dx.doi.org/10.1016/S0967-0637(96)00036-2

[32] Suryanarayana, A., Murty, V.S.N. and Rao, D.P. (1993) Hydrography and Circulation of the Bay of Bengal during Early Winter, 1983. Deep Sea Research I, 40, 205-217. http://dx.doi.org/10.1016/0967-0637(93)90061-7

[33] Murty, V.S.N., Sarma, Y.V.B., Rao, D.P. and Murty, C.S. (1992) Water Characteristics, Mixing and Circulation in the Bay of Bengal during Southwest Monsoon. Journal of Marine Research, 50, 207-228. http://dx.doi.org/10.1357/002224092784797700

[34] Vinayachandran, P.N., Masumoto, Y., Mikawa, T. and Yamagata, T. (1999) Intrusion of the Southwest Monsoon Current into the Bay of Bengal. Journal of Geophysical Research, 104, 11077-11085. http://dx.doi.org/10.1029/1999JC900035

[35] Han, W. and McCreary, J.P. (2001) Modeling Salinity Distributions in the Indian Ocean. Journal of Geophysical Research, 106, 859-877. http://dx.doi.org/10.1029/2000JC000316

[36] Vinayachandran, P.N. and Yamagata, T. (1998) Monsoon Response of the Sea around Sri Lanka: Generation of Thermal Domes and anti-Cyclonic Vortices. Journal of Physical Oceanography, 28, 1946-1960. 
[37] Gopalan, A.K.S., Gopala Krishna, V.V., Ali, M.M. and Sharma, R. (2000) Detection of Bay of Bengal Eddies from TOPEX and In-Situ Observations. Journal of Marine Research, 58, 721-734. http://dx.doi.org/10.1357/002224000321358873

[38] Murukesh, N. (2007) Roles of Eddies in the Bay of Bengal Circulation Hydrography and in the Distribution of Nutrients and Chlorophyll. PhD Thesis, Goa University, National Institute of Oceanography, Goa, India.

[39] Danabasoglu, G., McWilliams, J.C. and Gent, P.R. (1994) The Role of Mesoscale Tracer Transports in the Global Ocean Circulation. Science, 264, 1123-1126. http://dx.doi.org/10.1126/science.264.5162.1123

[40] Haidvogel, D.B., Arango, H.G., Hedstrom, K., Beckmann, A., Malanotte-Rizzoli, P. and Shchepetkin, A.F. (2000) Model Evaluation Experiments in the North Atlantic Basin: Simulations in Nonlinear Terrain-Following Coordinates. Dynamics of Atmospheres and Oceans, 32, 239-281. http://dx.doi.org/10.1016/s0377-0265(00)00049-X

[41] Moisan, J.R. (2003) Modeling the Coastal Ocean Processes within the U.S. Continental Margins. Earth Observation Magazine, 12, 10-12.

[42] Hedstorm, K.S. (1997) User's Manual for an S-Coordinate Primitive Equation Ocean Circulation Model (SCRUM) Version 3.0. Institute of Marine and Coastal Sciences, Rutgers University, 116 p.

[43] Large, W.G., McWilliams, J.C. and Doney, S.C. (1994) Oceanic Vertical Mixing: A Review and a Model with a Nonlocal Boundary Layer Parameterization. Reviews of Geophysics, 32, 363-403. http://dx.doi.org/10.1029/94rg01872

[44] Levitus, S. and Boyer, T.P. (1994) World Ocean Atlas 1994. Vol. 4, Temperature, US Government Printing Office, NOAA Atlas NESDIS 4, 117 p.

[45] Levitus, S., Burgett, R. and Boyer, T.P. (1994) World Ocean Atlas 1994. Vol. 5, Salinity, US Government Printing Office, Washington DC, NOAA Atlas NESDIS 3, 99 p.

[46] Boyer, T.P., Stephens, C., Antonov, J.I., Conkright, M.E., Locarnini, R.A., O’Brien, T.D. and Garcia, H.E. (2002) World Ocean Atlas 2001. Volume 2, Salinity, Levitus, S., Ed., NOAA Atlas NESDIS 50. US Government Printing Office, Washington DC.

[47] Stephens, C., Antonov, J.I., Boyer, T.P., Conkright, M.E., Locarnini, R.A., O’Brien, T.D. and Garcia, H.E. (2002) Temperature. Vol. 1, World Ocean Atlas 2001, NOAA Atlas NESDIS 49, 167 p.

[48] Song, Y.T. and Haidvogel, D.B. (1994) A Semi-Implicit Ocean Circulation Model Using a Generalized Topography Following Coordinate System. Journal of Computational Physics, 115, 228-248. http://dx.doi.org/10.1006/jcph.1994.1189

[49] Carter, E.F. and Robinson, A.R. (1987) Analysis Models for the Estimation of Oceanic Fields. Journal of Atmospheric and Oceanic Technology, 4, 49-74. http://dx.doi.org/10.1175/1520-0426(1987)004<0049:AMFTEO>2.0.CO;2

[50] Lermusiaux, P.F.J. (1999) Data Assimilation via Error Subspace Statistical Estimation, Part II: Middle Atlantic Bight Shelfbreak Front Simulations and Esse Validation. Monthly Weather Review, 1278, 1408-1432. http://dx.doi.org/10.1175/1520-0493(1999)127<1408:DAVESS>2.0.CO;2

[51] Calado, L., Gangopadhyay, A. and Silveria, I.C.A. (2008) Feature-Oriented Regional Modeling and Simulations (FORMS) for the Western South Atlantic: Southeastern Brazil Region. Ocean Modelling, 25, 48-64. http://dx.doi.org/10.1016/j.ocemod.2008.06.007

[52] Maltrud, E.M. and McClean, J. (2005) An Eddy Resolving Global 1/10 Ocean Simulation. Ocean Modelling, 8, 31-54. http://dx.doi.org/10.1016/j.ocemod.2003.12.001

[53] Shaji, C. and Gangopadhyay, A. (2007) Synoptic Modeling of the West India Coastal Current System Using an Upwelling Feature Model. Journal of Atmospheric and Oceanic Technology, 24, 877-893. http://dx.doi.org/10.1175/JTECH1984.1

[54] Kim, H.S., Gangopadhyay, A., Rosenfeld, L.K. and Bub, F.L. (2007) Developing a High-Resolution Climatology for the Central California Coastal Region. Continental Shelf Research, 27, 2135-3161. http://dx.doi.org/10.1016/j.csr.2007.05.011

[55] Schott, F., Reppin, J. and Fischer, J. (1994) Currents and Transports of the Monsoon Current South of Sri Lanka. Journal of Geophysical Research, 99, 25127-25141. http://dx.doi.org/10.1029/94JC02216

[56] Jensen, T.G. (2001) Arabian Sea and Bay of Bengal Exchange of Salt and Tracers in an Ocean Model. Geophysical Research Letters, 28, 3967-3970.

[57] Babu, M.T., Prasanna, K.S. and Rao, D.P. (1991) A Subsurface Cyclonic Eddy in the Bay of Bengal. Journal of Marine Research, 49, 403-410. http://dx.doi.org/10.1357/002224091784995846

[58] Yu, L.L., O’Brien, J.J. and Yang, J. (1991) On the Remote Forcing of Circulation in the Bay of Bengal. Journal of Geophysical Research, 96, 20449-20454. http://dx.doi.org/10.1029/91JC02424

[59] Niiler, P.P., Davis, R. and White, H. (1987) Water-Following Characteristics of a Mixed-Layer Drifter. Deep Sea Re- 
search, 34, 1867-1882. http://dx.doi.org/10.1016/0198-0149(87)90060-4

[60] Hansen, D. and Poulain, P.M. (1996) Quality Control and Interpolations of WOCE-TOGA Drifter Data. Journal of Atmospheric and Oceanic Technology, 13, 900-909. http://dx.doi.org/10.1175/1520-0426(1996)013<0900:QCAIOW>2.0.CO;2

[61] Niiler, P.P. (2001) The World Ocean Surface Circulation. In: Siedler, G., Church, J. and Gould, J., Eds., Ocean Circulation and Climate, Volume 77 of International Geophysics Series, Academic Press, San Diego, 193-204.

[62] Lumpkin, R. (2003) Decomposition of Surface Drifter Observations in the Atlantic Ocean. Geophysical Research Letters, 30, 1753. http://dx.doi.org/10.1029/2003gl017519

[63] Jensen, T.G. (1993) Equatorial Variability and Response in a Wind Driven Indian Ocean Model. Journal of Geophysical Research, 98, 22533-22552. http://dx.doi.org/10.1029/93JC02565

[64] Rao, R.R., Molinari, R.L. and Festa, J.F. (1989) Evolution of the Climatological Near-Surface Thermal Structure of the Tropical Indian Ocean. Journal of Geophysical Research, 94, 10801-10815. http://dx.doi.org/10.1029/JC094iC08p10801 